Review Article

\title{
Urea-Assisted Synthesis and Characterization of Saponite with Different Octahedral (Mg, Zn, Ni, Co) and Tetrahedral Metals (Al, Ga, B), A Review
}

\author{
Concepcion Ponce ${ }^{1}$ and J. Theo Kloprogge $\mathrm{e}^{1,2^{*}}$ \\ ${ }^{1}$ Department of Chemistry, College of Arts and Sciences, University of the Philippines, Miag-ao, Iloilo, \\ Philippines \\ ${ }^{2}$ School of Earth and Environmental Sciences, The University of Queensland, Brisbane, Queensland 4072, \\ Australia \\ * Correspondence: j.kloprogge@uq.edu.au
}

\begin{abstract}
Clay minerals surfaces potentially played a role in prebiotic synthesis through adsorption of organic monomers that give rise to highly concentrated systems; facilitate condensation and polymerization reactions; protection of early biomolecules from hydrolysis and photolysis; and surface-templating for specific adsorption and synthesis of organic molecules. This review presents processes of clay formation using saponite as a model clay mineral since it is shown to catalyze organic reactions, easy to synthesize in large and pure form, and has tunable properties. In particular, a method involving urea is presented as a reasonable analog of natural processes. The method involves a two-step process -1) formation of the precursor aluminosilicate gel and 2) hydrolysis of a divalent metal $(\mathrm{Mg}, \mathrm{Ni}, \mathrm{Co}, \mathrm{Zn})$ by the slow release of ammonia from urea decomposition. The aluminosilicate gels in the first step forms a 4 -fold-coordinated $\mathrm{Al}^{3+}$ similar to what is found in nature such as in volcanic glass. The use of urea, a compound figuring in many prebiotic model reactions, circumvents the formation of undesirable brucite, $\mathrm{Mg}(\mathrm{OH})_{2}$, in the final product by slowly releasing ammonia thereby controlling the hydrolysis of magnesium. In addition, the substitution of $B$ and Ga for $\mathrm{Si}$ and $\mathrm{Al}$ in saponite is also described The saponite products from this urea-assisted synthesis were tested as catalysts for several organic reactions including Friedel-Crafts alkylation, cracking and isomerization reactions.
\end{abstract}

Keywords: clay minerals; heterogeneous catalysis; saponite; synthesis; urea 


\section{Introduction}

Clay minerals are a group of minerals that occur as colloidal crystals in sediments and soils. They consist mostly of hydrated aluminum phyllosilicates, that may contain variable amounts of iron, magnesium, alkali metals, alkaline earths, and other cations found on or near some planetary surfaces. They are abundant and widely distributed in nature showing a wide variety of structures, compositions, and properties. Clay minerals have been posited to figure prominently in the origin of life. Bernal was the first to point to the potential role of clay minerals in abiogenesis [1]. He suggested that surfaces of clay minerals are the likely location where primitive biomolecules that occurred in the "primordial soup" could concentrate and be available for further reactions. Cairns-Smith and Hartman forwarded the clay hypothesis and postulated that complex organic molecules arose gradually on pre-existing, non-organic replication surfaces of silicate crystals in solution [2]. A few others have supported the importance of clays in the synthesis of simple and organic molecules that are the building blocks of life. Among them are Balogh and Laszlo who provided an overview of organic reactions catalyzed by clays, whether natural, activated and modified, including pillared clays or performed by clay-supported reagents [3]. Ferris and his group showed that ribonucleic acid (RNA) oligomers (RNAs are capable of both information storage and as templates to catalyze the synthesis of complementary molecules) can be synthesized on the surfaces of montmorillonite [4-7]. These montmorillonite surfaces were also shown to influence the regioselectivity of the RNA oligomers. [5]. The indication that clay surfaces played an important role came about because the environment of the early ocean would favor the following phenomena: 1) slow synthesis of the amino acids, nucleotides and other building blocks of life; 2) thermodynamically-hindered formation of proteins, RNA and DNA from these building blocks; and 3) more favored hydrolysis and photolysis of these complexes. Adsorption onto surfaces and their consequent interfacial interactions have been shown to overcome these obstacles. In fact, Huang and Ferris had developed a "one step," no primer method for the synthesis of RNA oligomers in the presence of clays [8]. Negron-Mendoza et al. further espoused that the most geologically relevant solid surfaces to promote chemical reactions on the primitive Earth are clay minerals [9]. Such claims are based on observations that clay minerals are ubiquitous minerals on Earth and very likely appeared in the early steps of the formation of our planet; they have been possibly present at least $3.8 \times 10^{9}$ years ago as indicated in the analysis of the Isua sediments in Greenland [10].

The surfaces of clay minerals may have played a role in prebiotic synthesis through adsorption of monomers that give rise to highly concentrated systems; facilitate condensation and polymerization reactions; protection of early biomolecules from hydrolysis and photolysis; and surface-templating for specific adsorption and synthesis of organic molecules. Several clay minerals such as smectite-type clays $[11,12]$ including montmorillonite $[5,6,13-16]$ and saponite $[12,17]$, layered double hydroxides $[18,19]$, etc. were experimentally shown to play these roles. While papers on the origin of life centered more on the role of clay minerals in prebiotic synthesis as seen in reviews by Ponnamperuma et al. [20], Ferris [21], and Brack [22], this review presents processes of clay formation using saponite as a model clay mineral since an understanding of how clay minerals are formed is key to understanding the roles played by these minerals in the origin of life. Small organic molecules present in hydrothermal fluids that permeated through the pores of early Earth's crust could have assisted in the formation of clay minerals. This in turn could have formed clay microenvironments for adsorption and interaction with other organic molecules which could have led to the formation of more complex organic molecules like DNA or RNA, proteins, etc.

The choice of saponite is based on studies that show Fe-rich saponite were able to promote and preserve precursors of biopolymers and this may have contributed to prebiotic chemistry on Earth and the deep biosphere [17]. Sueoka et al. studied the mineral-filled fractures of a basaltic rock core sample obtained during Integral Ocean Drilling Project Expedition 329 and found that these minerals were rich in Mg-rich saponite and calcium carbonate [23]. The saponite-rich clay fraction in the core contains a much higher organic carbon than the bulk counterpart suggesting enough supply of energy and carbon sources for a saponite-hosted life [23]. Apart from the possible contributions of 
saponites to early life, another reason for the interest in the system is the observation that saponites are easy to synthesize and their structures can be functionalized and modulated to obtain a wide variety of interesting novel advanced layered materials for use in heterogeneous catalysis [17] or for protection of organic compounds from photolysis [24]. In addition to the choice of saponite as this article's focus, urea, a compound easily formed by the hydrolysis of cyanide and is often used as model compound in classic prebiotic reactions is also given emphasis. Urea is a very interesting molecule. Its structure and properties make it a potentially good starting material for the synthesis of nucleobases and related molecules $[25,26]$. It has been shown to promote phosphorylation reactions $[25,26]$. Moreover, it was able to catalyze formation of saponite clays in only $20 \mathrm{~h}$ under relatively mild conditions [27]. This review, thus, presents the 1) various methods of preparation of saponite clays giving emphasis to those syntheses where urea plays a significant role; 2) tools that follow and ascertain their formation from precursor materials as well as probe their structural and property changes as they interact with their environment; and 3) thermal stability and catalytic properties of synthetic saponites.

\section{Saponite Synthesis and Characterization}

\subsection{Saponite Composition and Occurrence}

Saponite is a 2:1 type trioctahedral member of the smectite group of clay minerals with the theoretical chemical formula $\mathrm{Ca} 0.25(\mathrm{Mg}, \mathrm{Fe})_{3}\left((\mathrm{Si}, \mathrm{Al})_{4} \mathrm{O}_{10}\right)(\mathrm{OH})_{2} \cdot \mathrm{n}\left(\mathrm{H}_{2} \mathrm{O}\right)$. Calcium can be substituted by sodium $\left(\mathrm{Na}^{+}\right)$and potassium $\left(\mathrm{K}^{+}\right)$cations. $\mathrm{Mg}^{2+}$ dominates in the octahedral sheets but with some $\mathrm{Al}^{3+}$, $\mathrm{Fe}^{2+}, \mathrm{Fe}^{3+}, \mathrm{Li}^{+}, \mathrm{Mn}^{2+}, \mathrm{Ni}^{2+}$, and $\mathrm{Ti}^{4+}$ substitutions occurring while $\mathrm{Al}^{3+}$ and $\mathrm{Fe}^{3+}$ for $\mathrm{Si}^{4+}$ substitutions occur in the tetrahedral sheets (Figure 1) [27]. Saponite is soft, massive, and plastic, and exists in hydrothermal veins; basalt vesicles; and fissures cutting calc-silicates, iron-rich skarns, amphibolites and serpentinites. The name is derived from the Latin sap, making allusion to its greasy and soapy feel and appearance.

\subsection{Preparation Methods}

Several preparation methods of synthetic saponites with tunable composition and physicochemical properties have been reported in literature. These methods are grouped into sol-gel processes under mild temperatures and pressures; hydrothermal processes which are carried out at relatively higher temperatures and pressures; and microwave-assisted hydrothermal synthesis, which allows for synthesis to occur at a temperature lower than typical hydrothermal methods and at a much shorter timescale. Table 1 summarizes the starting materials and conditions for the synthesis of saponites. 


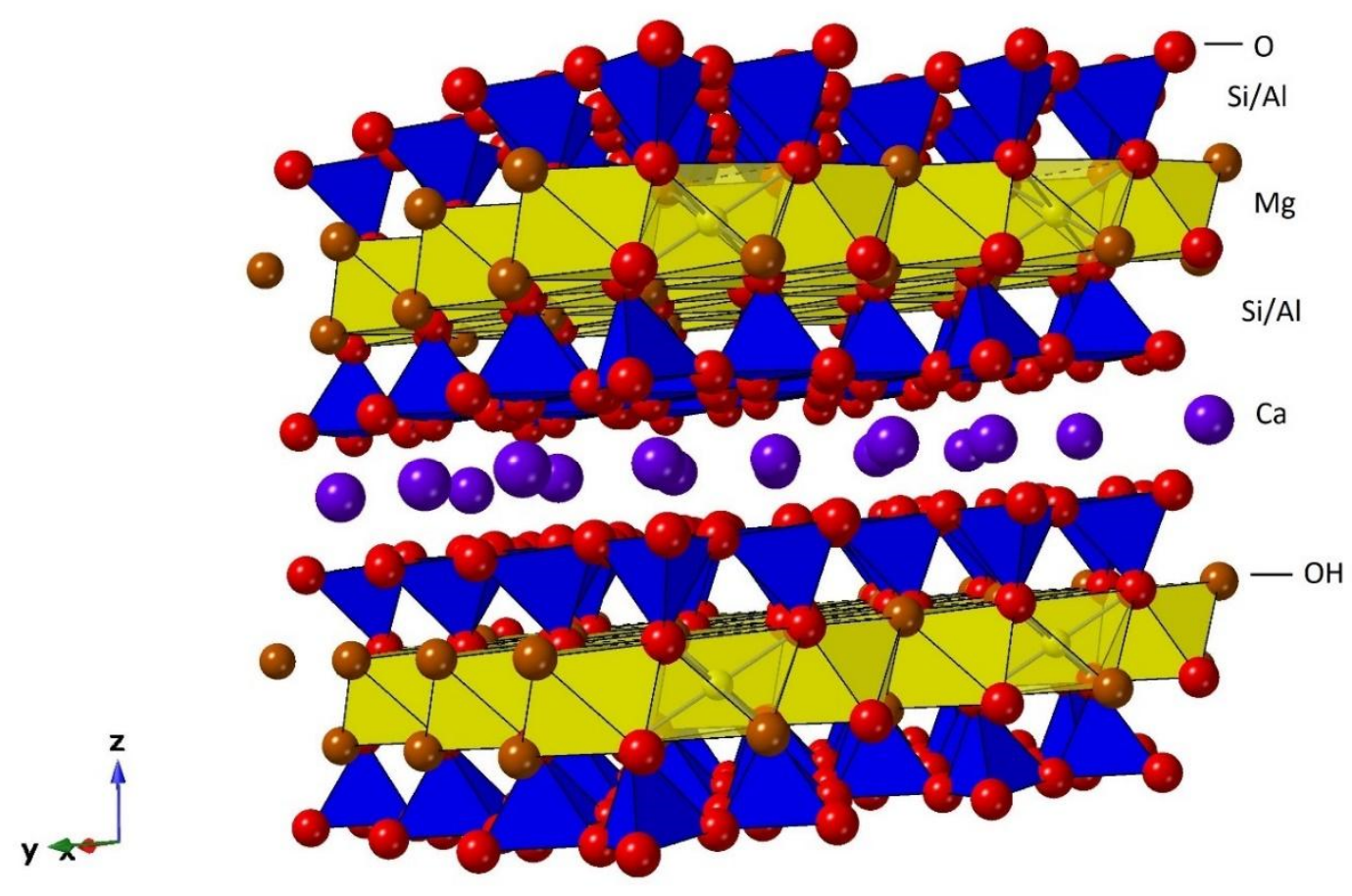

Figure 1. A schematic representation of saponites showing the major elements occupying the tetrahedral, octahedral sheets and interlayer spaces.

The hydrothermal methods are the most explored procedures for the synthesis of saponites. Kloprogge and his co-researchers presented several works on the hydrothermal synthesis of saponites [28-32]. Their works suggested that hydrothermal techniques are successful in obtaining pure products due to the high hydrolysis rates of the octahedral cations precursors at high temperature, which favor nucleation and growth of saponite materials. Hydrothermal methods involve a gel with stoichiometric mixture of silica, $\mathrm{Al}$ and $\mathrm{Mg}$ salts and a source of interlayer cations (typically sodium or ammonium) which is treated under hydrothermal conditions at temperatures ranging from $150-450{ }^{\circ} \mathrm{C}$ under autogenous water pressures for a period of $5 \mathrm{~min}$ to as long as 3 months (Table 1). 
Table 1. Saponite synthesis methods

\begin{tabular}{|c|c|c|c|c|}
\hline Author/s, Year & Starting Materials & Conditions & $\begin{array}{c}\text { Product/Product } \\
\text { Properties }\end{array}$ & Notes \\
\hline $\begin{array}{l}\text { Kloprogge et al., } \\
1993 \text { [28] }\end{array}$ & 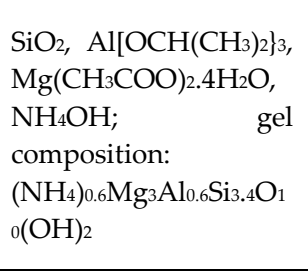 & $\begin{array}{l}\text { Autoclave at } 125 \text { to } 280 \\
{ }^{\circ} \mathrm{C} \text { for } 72 \text { hours }\end{array}$ & $\begin{array}{l}\mathrm{NH}_{4} \text {-saponite - high } \\
\text { crystallinity, low CEC, } \\
\text { high Al content in } \\
\text { interlayer spacing or in } \\
\text { octahedral sites }\end{array}$ & $\begin{array}{l}\text { uncontrolled } \\
\text { intercalation of } \mathrm{Al}^{3+} \text { in } \\
\text { the interlayer; non- } \\
\text { swelling saponites } \\
\text { with low amounts of } \\
\mathrm{NH}^{4+} \text {; deceased } \\
\text { catalytic activity }\end{array}$ \\
\hline $\begin{array}{l}\text { Kloprogge et al., } \\
1994 \text { [29] }\end{array}$ & $\begin{array}{l}\text { modified from } \\
\text { Kloprogge et al., 1993; } \\
\text { solutions containing } \\
\text { the desired cation were } \\
\text { in the form of a } \\
\text { hydroxide or fluoride } \\
\text { salt; gel composition: } \\
(\mathrm{M}) .6 \mathrm{Mg}_{3} \mathrm{Al}_{0.6 \mathrm{Si}} .4 \mathrm{O}_{10}( \\
\mathrm{OH})_{2} ;\left(\mathrm{M}=\mathrm{Na}^{+}, \mathrm{K}^{+}\right. \\
\left.\mathrm{Rb}^{+}, \mathrm{Ca}^{2+}, \mathrm{Ba}^{2+}, \text { or } \mathrm{Ce}^{4+}\right)\end{array}$ & $\begin{array}{l}\text { Autoclave at } 200{ }^{\circ} \mathrm{C} \\
\text { and autogenous water } \\
\text { pressure for } 72 \text { hours }\end{array}$ & $\begin{array}{l}\text { Mg-saponite - low } \\
\text { CEC, low stacking of } \\
\text { saponite sheets; } \\
\text { considerable } \\
\text { octahedral aluminum } \\
\text { substitution; }\end{array}$ & $\begin{array}{l}\text { 1) the presence of } \\
\text { interlayer } \mathrm{Mg}^{2+} \text { and the } \\
\text { absence of interlayer } \\
\mathrm{Al}^{3+} ; 2 \text { ) a much higher } \\
\text { amount of octahedral } \\
\mathrm{AI} \text {; and 3) that } \\
\text { synthesis experiments } \\
\text { with fluorine do not } \\
\text { result in incorporation } \\
\text { of extensive F- into the } \\
\text { saponite structure } \\
\text { replacing hydroxyl } \\
\text { groups, nor in the } \\
\text { formation of sellaite, } \\
\mathrm{MgF}_{2}\end{array}$ \\
\hline $\begin{array}{l}\text { Kawi and Yao, } \\
1999 \text { [33] }\end{array}$ & $\begin{array}{l}\text { sodium silicate } \\
\text { solution; } \\
\mathrm{NaOH} / \mathrm{NaHCO}_{3} ; \\
\text { chlorides of } \mathrm{M}^{3+}=\mathrm{Al}^{3+}, \\
\text { and } \mathrm{M}^{2+}=\mathrm{Mg}^{2+}, \mathrm{Ni}^{2+} ; \\
\text { saponite of theoretical } \\
\text { formula }\left[\mathrm{MgxNi}_{6}-\right. \\
\mathrm{x}](\mathrm{Si} 7 \mathrm{Al}) \mathrm{O}_{20}(\mathrm{OH})_{4}\end{array}$ & $\begin{array}{l}\text { Autoclave at } 285^{\circ} \mathrm{C} \text { for } \\
48 \mathrm{~h}\end{array}$ & $\begin{array}{l}\text { saponite with varied } \\
\mathrm{Mg} / \mathrm{Ni} \text { ratio }\end{array}$ & $\begin{array}{l}\mathrm{Mg} \text { and } \mathrm{Ni} \text { were } \\
\text { incorporated in } \\
\text { octahedral sites; tested } \\
\text { as catalyst for } \\
\text { dehydration of IPA to } \\
\text { propene and } \\
\text { dehydrogenation to } \\
\text { acetone }\end{array}$ \\
\hline $\begin{array}{l}\text { Vogels et al., } \\
1997[31]\end{array}$ & $\begin{array}{l}\text { modified from } \\
\text { Kloprogge et al., 1993; } \\
\text { stoichiometric powder } \\
\text { mix of } \mathrm{SiO}_{2} \text { and } \\
\mathrm{Mg}\left(\mathrm{CH}_{3} \mathrm{COO}\right)_{2} .4 \mathrm{H}_{2} \mathrm{O} ; \\
\mathrm{NH} \mathrm{O}_{4} \mathrm{Cl} \text { or } \mathrm{NH}_{4} \mathrm{~F} \text { with } \\
\text { the } \mathrm{Al}\left[\mathrm{OCH}\left(\mathrm{CH}_{3}\right)_{2}\right\}_{3} \\
\text { dissolved in the } \\
\text { aqueous ammonium } \\
\text { solutions before } \\
\text { mixing with the } \\
\text { powder }\end{array}$ & $\begin{array}{l}\text { Autoclave at } 200^{\circ} \mathrm{C} \\
\text { and autogenous water } \\
\text { pressure; varying } \\
\text { synthesis time }\end{array}$ & $\mathrm{NH}_{4}$-saponite & $\begin{array}{l}\text { The crystallinity of } \\
\text { synthetic ammonium- } \\
\text { saponite depends } \\
\text { strongly on synthesis } \\
\text { time, ammonium } \\
\text { concentration and } \\
\text { initial constituents of } \\
\text { the gel. }\end{array}$ \\
\hline $\begin{array}{l}\text { Higashi, Miki } \\
\text { and } \\
\text { Komarmeni, } \\
2007[34]\end{array}$ & $\begin{array}{l}\text { silicic acid (containing } \\
\left.81.4 \% \mathrm{SiO}_{2}\right), \quad \mathrm{MnCO}_{3} \text {, } \\
\mathrm{Al}\left(\mathrm{NO}_{3}\right)_{3} \square 9 \mathrm{H}_{2} \mathrm{O}, \\
\mathrm{NaOH} \text { solution }\end{array}$ & $\begin{array}{l}\text { Autoclave at } 100-250 \\
{ }^{\circ} \mathrm{C} \text { under autogenous } \\
\text { pressure for } 72-168 \mathrm{~h}\end{array}$ & $\begin{array}{l}\text { Mn-saponite with Mn- } \\
\text { carbonate impurities }\end{array}$ & $\begin{array}{l}\text { Was not analyzed } \\
\text { further due to poor } \\
\text { crystallinity. }\end{array}$ \\
\hline $\begin{array}{l}\text { Carniatto et al., } \\
2009 \text { [35] }\end{array}$ & $\begin{array}{l}\text { modified from } \\
\text { Kloprogge et al., } 1993 \text {; } \\
\mathrm{SiO}_{2} \text {, } \mathrm{Al}\left[\mathrm{OCH}\left(\mathrm{CH}_{3}\right)_{2}\right]_{3} \text {, } \\
\mathrm{Mg}\left(\mathrm{CH}_{3} \mathrm{COO}\right)_{2} .4 \mathrm{H}_{2} \mathrm{O} \text {, } \\
\mathrm{NH}_{4} \mathrm{OH}, \\
\text { vanadium(IV) oxide } \\
\text { sulphate hydrate } \\
\text { (VOSO } 4 \text { xH } \mathrm{xH}_{2} \mathrm{O} ; \\
\text { tetraethyl orthosilicate } \\
\text { (TEOS); acidified } \\
\text { ethanol }\end{array}$ & $\begin{array}{l}\text { Autoclave at } 240^{\circ} \mathrm{C} \text { for } \\
72 \mathrm{~h}\end{array}$ & V-saponite, crystalline & $\begin{array}{l}\text { Strong potential as } \\
\text { additive for polymer } \\
\text { materials with flame } \\
\text { retardant properties. }\end{array}$ \\
\hline
\end{tabular}




\begin{tabular}{|c|c|c|c|c|}
\hline $\begin{array}{l}\text { Bisio et al., } 2011 \\
\text { [36] }\end{array}$ & $\begin{array}{l}\text { modified from } \\
\text { Kloprogge et al., 1993; } \\
\text { the reagents } \\
\text { enumerated to form } \\
\text { the gel in Kloprogge et } \\
\text { al., } 1993 \text { were added } \\
\text { with } \\
\text { hexadecyltrimethylam } \\
\text { monium bromide } \\
\text { (CTABr) }\end{array}$ & $\begin{array}{l}\text { Autoclave at } 200{ }^{\circ} \mathrm{C} \text { for } \\
72 \mathrm{~h}\end{array}$ & organo-saponite & $\begin{array}{l}\text { CTA- ions are } \\
\text { essentially confined in } \\
\text { the interlayer space of } \\
\text { the saponite. }\end{array}$ \\
\hline $\begin{array}{lr}\text { Sychev } & \text { and } \\
\text { Prihod'ko, } 1998 \\
{[37]}\end{array}$ & $\begin{array}{l}\mathrm{Na}_{2} \mathrm{SiO}_{3} ; \mathrm{NaOH} ; \mathrm{M}^{3+}- \\
\text { nitrate where } \mathrm{M}=\mathrm{Al} \text {, } \\
\text { Fe or } \mathrm{Cr} \text {; aqueous } \mathrm{M}^{2+} \\
\text { nitrate and urea; } \mathrm{Si} / \mathrm{M}^{3+} \\
\text { ratio is varied from } 3.0- \\
12\end{array}$ & $\begin{array}{l}\text { Sol-gel precipitation at } \\
190^{\circ} \mathrm{C} \text { at } 1 \text { atm for } 24 \\
\text { hours }\end{array}$ & $\begin{array}{l}\text { saponite like materials; } \\
\text { poor crystallinity; high } \\
\text { CEC }\end{array}$ & $\begin{array}{l}\text { Possess acidic and } \\
\text { basic/redox active sites } \\
\text { which depends on the } \\
\text { chemical composition } \\
\text { of both tetrahedral and } \\
\text { octahedral sheets of } \\
\text { saponite. }\end{array}$ \\
\hline $\begin{array}{l}\text { Vogels et al., } \\
2005 \text { [27] }\end{array}$ & $\begin{array}{l}\text { stoichiometric mixture } \\
\text { containing } \mathrm{Si} / \mathrm{Al}^{3+} \text { gel } \\
\text { from } \mathrm{Na}_{2} \mathrm{SiO}_{3} \text { solution } \\
\text { and } \mathrm{Al}\left(\mathrm{NO}_{3}\right)_{3} \square 9 \mathrm{H}_{2} \mathrm{O} ; \\
\mathrm{NaOH} \text { solution, } \mathrm{M}^{2+} \\
\text { nitrate } \mathrm{(M}^{2+}=\mathrm{Mg}^{2+} \text {, } \\
\mathrm{Zn}^{2+}, \mathrm{Ni}^{2+}, \mathrm{Co}^{2+}, \text { or } \\
\left.\mathrm{Cu}^{2+}\right) \text {, urea, and water }\end{array}$ & $\begin{array}{l}\text { Sol-gel } \\
\text { precipitation at } 90{ }^{\circ} \mathrm{C} \\
\text { for } 20 \text { hours }\end{array}$ & $\begin{array}{l}\mathrm{M}^{2+} \text {-saponites where } \\
\mathrm{M}^{2+}=\mathrm{Mg}^{2+}, \mathrm{Zn}^{2+}, \mathrm{Ni}^{2+}, \\
\left.\mathrm{Co}^{2+}, \text { or } \mathrm{Cu}^{2+}\right)\end{array}$ & $\begin{array}{l}\text { Thermal stability } \\
\text { increases in order } \mathrm{Zn}^{2+} \text {, } \\
\mathrm{Co}^{2+}, \mathrm{Mg}^{2+}, \text { to } \mathrm{Ni}^{2+} \text { from } \\
450 \text { to } 800{ }^{\circ} \mathrm{C} \text { and is } \\
\text { determined by the } \\
\text { nature of the } \\
\text { octahedral cation. }\end{array}$ \\
\hline $\begin{array}{lr}\text { Xue } & \text { and } \\
\text { Pinnavaia, } 2008 \\
{[38]}\end{array}$ & $\begin{array}{l}\text { Modified from Vogels } \\
\text { et al., 2005; } \\
\text { stoichiometric mixture } \\
\text { containing } \mathrm{Si} / \mathrm{Al}^{3+} \text { gel } \\
\text { from water glass } \\
\text { solution, } \\
\mathrm{Al}\left(\mathrm{NO}_{3}\right)_{3} \square 9 \mathrm{H}_{2} \mathrm{O} \text {, } \\
\mathrm{Mg}\left(\mathrm{NO}_{3}\right)_{2} \square 6 \mathrm{H}_{2} \mathrm{O} \text {, urea } \\
\text { and water in a molar } \\
\text { ratio of } 6.6: 0.40: 3.0: 10 \\
\text { per } 400 \text { moles of water }\end{array}$ & $\begin{array}{l}\text { Sol-gel } \\
\text { precipitation at } 90{ }^{\circ} \mathrm{C} \\
\text { for } 24 \text { hours }\end{array}$ & $\begin{array}{l}\text { saponite, } \\
\text { crystallinity, } \quad \text { poor } \\
\text { surface area, BJH pore } \\
\text { volume and pore size }\end{array}$ & $\begin{array}{l}\text { Has decent } \\
\text { transparency when } \\
\text { incorporated in glassy } \\
\text { epoxy polymer. }\end{array}$ \\
\hline $\begin{array}{l}\text { Schumann et al., } \\
2012 \text { [39] }\end{array}$ & 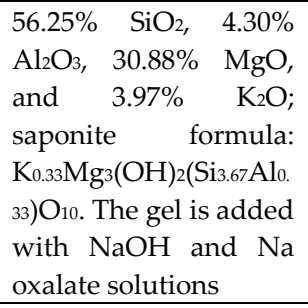 & $\begin{array}{l}\text { Sol-gel precipitation at } \\
60{ }^{\circ} \mathrm{C} \text { and ambient } \\
\text { pressure for } 3 \text { months! }\end{array}$ & $\begin{array}{l}\text { predominantly } \\
\text { saponite with } \mathrm{Mg}^{2+} \text { in } \\
\text { interlayers and talc } \\
\text { byproduct }\end{array}$ & $\begin{array}{l}\text { Gives replicating clay } \\
\text { minerals; possibly } \\
\text { through template- } \\
\text { catalyzed } \\
\text { polymerization, } \\
\text { charge distribution } \\
\text { transmitted from layer } \\
\text { to layer. }\end{array}$ \\
\hline $\begin{array}{l}\text { Besselink et al., } \\
2020 \text { [40] }\end{array}$ & $\begin{array}{l}\text { Modified from Vogels } \\
\text { et al., } 2005\end{array}$ & $\begin{array}{l}\text { 2-step sol-gel co- } \\
\text { precipitation at } 25-95 \\
{ }^{\circ} \mathrm{C} \text { at varying synthesis } \\
\text { time from } 5 \text { min to } 90 \\
\text { days }\end{array}$ & $\begin{array}{l}\text { Mg-saponite } \\
\text { nanocrystals; }\end{array}$ & $\begin{array}{l}\text { Two-step saponite } \\
\text { crystallization - 1) } \\
\text { amorphous } \\
\text { aluminosilicate } \\
\text { network formation, 2) } \\
\text { crystallization of this } \\
\text { amorphous } \\
\text { aluminosilicate } \\
\text { network towards } \\
\text { saponite in the } \\
\text { presence of } \\
\text { magnesium and urea. }\end{array}$ \\
\hline $\begin{array}{l}\text { Vicente, I. et al., } \\
2010 \text { [41] }\end{array}$ & $\begin{array}{l}\text { slurry }(\approx 9 \text { wt. } \% \text { solids), } \\
\text { with a } \\
\mathrm{Si}^{4+}: \mathrm{Al}^{3+}: \mathrm{Mg}^{2+}: \mathrm{NH}_{4}{ }^{+} \\
\text {composition ratio of } \\
14.3: 2.5: 12.5: 8 \text { which } \\
\text { would result in } \\
\text { saponite with the }\end{array}$ & $\begin{array}{l}\text { Microwave, } 180^{\circ} \mathrm{C} \text { for } \\
6 \mathrm{hrs}\end{array}$ & $\begin{array}{l}\mathrm{NH}_{4} \text {-saponite; } \\
\text { have } \begin{array}{r}\text { some } \\
\text { higher }\end{array} \\
\text { crystallinity, higher } \\
\mathrm{CEC} \text { and higher } \\
\mathrm{Al}(\mathrm{Td}) / \mathrm{Al}(\mathrm{Oh}) \text { ratio of } \\
\text { saponites formed }\end{array}$ & $\begin{array}{l}\text { Physico-chemical } \\
\text { properties of resulting } \\
\text { saponite is influenced } \\
\text { by initial slurry pH }\end{array}$ \\
\hline
\end{tabular}




\begin{tabular}{|c|c|c|c|c|}
\hline & $\begin{array}{l}\text { theoretical formula } \\
\left(\mathrm{NH}_{4}\right)_{1.2}\left[\mathrm{Mg}_{6} \mathrm{Al}_{1.2} \mathrm{Si}_{6.8} \mathrm{O}_{2}\right. \\
\left.{ }_{0}(\mathrm{OH})_{4}\right]\end{array}$ & & & \\
\hline $\begin{array}{l}\text { Trujillano et al., } \\
2011 \text { [42] }\end{array}$ & $\begin{array}{l}\text { sodium silicate } \\
\text { solution }(27 \% \quad \text { wt, } \\
\mathrm{d}=1.39 \mathrm{~g} / \mathrm{mL}) ; \mathrm{NaOH} \\
\text { and } \mathrm{NaHCO}_{3} ; \\
\text { chlorides } \mathrm{M}^{3+}=\mathrm{Al}^{3+} \text { or } \\
\mathrm{Fe}^{3+} \text { and } \mathrm{M}^{2+}= \\
\mathrm{Mg}^{2+}, \mathrm{Ni}^{2+}, \text { or } \mathrm{Fe}^{2+} ; \\
\text { saponite theoretical } \\
\text { formula } \\
{\left[\mathrm{Si}^{2} \mathrm{M}^{3+}\right]\left[\mathrm{M}^{2+}{ }_{6} \mathrm{O}_{20}(\mathrm{OH})_{4}\right.} \\
\mathrm{Na}_{2} \mathrm{nH}\end{array}$ & $\begin{array}{l}\text { Microwave, } 180{ }^{\circ} \mathrm{C} \text { for } \\
8 \mathrm{~h}\end{array}$ & $\begin{array}{l}\text { saponites containing } \\
\text { divalent } \mathrm{Mg} \text {, } \mathrm{Ni} \text { or } \mathrm{Fe} \text { - } \\
\text { large surface area }\end{array}$ & $\begin{array}{l}\text { A potentially good } \\
\text { oxidation catalyst } \\
\text { especially for NiMgAl; } \\
\text { possible synergistic } \\
\text { effect takes place when } \\
\text { two different cations } \\
\text { are present in adjacent } \\
\text { octahedral positions }\end{array}$ \\
\hline $\begin{array}{l}\text { Gebretsadik et } \\
\text { al., } 2015 \text { [43] }\end{array}$ & $\begin{array}{l}\text { modified from } \\
\text { Trujillano, et al., } 2011 \\
\text { and Gebretsadik et al., } \\
2014\end{array}$ & $\begin{array}{l}\text { Microwave, } 180{ }^{\circ} \mathrm{C} \text { for } \\
6 \mathrm{~h}\end{array}$ & $\begin{array}{l}\text { Na-saponite, } \quad \mathrm{NH}_{4}- \\
\text { saponite }\end{array}$ & $\begin{array}{l}\text { Characterized by } \\
\text { higher delamination } \\
\text { with smaller lamella } \\
\text { and higher } \mathrm{BET} \text { area; } \\
\text { higher } \\
\text { incorporation of } \mathrm{Al} \text { in } \\
\text { the tetrahedral sheet } \\
\text { (higher } \mathrm{Al}(\mathrm{T}) / \mathrm{Al}(\mathrm{O}) \\
\text { ratio) }\end{array}$ \\
\hline
\end{tabular}

Noteworthy is the mild non-hydrothermal synthesis procedure for saponite described by Vogels et al. as it allowed scaled up preparation as well as easy tunability of the texture and composition of the saponites $[27,44,45]$. The method involves a precursor mixture with a saponite theoretical composition of $\mathrm{N}_{\mathrm{x} / \mathrm{z}^{++}}\left[\mathrm{M}_{6}\right]\left[\mathrm{Si}_{8-\mathrm{x}} \mathrm{Al}_{\mathrm{x}}\right] \mathrm{O}_{20}(\mathrm{OH})_{4} \cdot \mathrm{nH}_{2} \mathrm{O}$. M and $\mathrm{N}$ correspond to the divalent octahedral and the interlayer cations, respectively. The octahedral cation, $\mathrm{M}$, is used as prefix to name the saponites such as $\mathrm{Zn}$-saponite when the octahedral cation is $\mathrm{Zn}^{2+}$. The experiments were performed at a constant mild temperature of $90^{\circ} \mathrm{C}$ for 20 hours (unless otherwise indicated) in a double-walled Pyrex vessel which had stirrer and baffles that ensured homogeneity of the mixture within. A gel with 5.67 $(x=1.2) \mathrm{Si} / \mathrm{Al}$ molar ratio was made by diluting $\mathrm{Na}_{2} \mathrm{SiO}_{3}$ solution $\left(27 \mathrm{wt} \% \mathrm{SiO}_{2}\right)$ in demineralized water and gradually adding under constant stirring a previously prepared $\mathrm{Al}(\mathrm{OH})^{-}$(from $\mathrm{Al}\left(\mathrm{NO}_{3}\right)_{3} \cdot 9 \mathrm{H}_{2} \mathrm{O}$ in $\mathrm{NaOH}$ solution) to form the gel. Several more gels with $\mathrm{Si} / \mathrm{Al}$ molar ratios of 7.89 $(\mathrm{x}=0.9)$ and $12.3(\mathrm{x}=0.6)$ were prepared similarly by adjusting the amounts of the aluminum and silicate sources. In all the experiments, the sum of $\mathrm{Si}+\mathrm{Al}$ was kept constant. Gels with an exceptionally low $\mathrm{Si} / \mathrm{Al}$ ratio of $2.33(\mathrm{x}=2.4)$, the aluminum nitrate was not added with $\mathrm{NaOH}$ to decrease the rate of gelation. However, for a gel with a $\mathrm{Si} / \mathrm{Al}$ ratio of $39.0(\mathrm{x}=0.2)$, the preparation was modified because the authors observed that after mixing the Si- and Al-containing solutions, no gels were formed. Only after addition of an appropriate amount of $\mathrm{HNO}_{3}(65 \%)$ was a stable white gel formed. The gels that were formed were then added to demineralized water, placed in the aforementioned vessel and the temperature increased to $90{ }^{\circ} \mathrm{C}$. Synthesis was started when the gelwater mixture (maintained at $90{ }^{\circ} \mathrm{C}$ ) was added with the needed amounts nitrates of $\mathrm{M}^{2+}$ cations $\left(\mathrm{M}^{2+}\right.$ $=\mathrm{Mg}^{2+}, \mathrm{Ni}^{2+}, \mathrm{Zn}^{2+}, \mathrm{Co}^{2+}$, and $\mathrm{Cu}^{2+}$ ) and urea dissolved in water. When the saponites were desired to have octahedral sheets with two metal cations whose ratio varied from 1 and 29, appropriate amounts of the divalent metal nitrate salts were combined in the synthesis mixtures. The prepared mixtures were not acidified before the start of the synthesis because the gels were unstable in acid conditions. The effect of urea concentration, which was used as the hydrolyzing agent, on saponite formation was investigated by using Zn-saponite as a test sample. In addition, a synthesis was performed where the $\mathrm{pH}$ of the initial mixture was 8 (achieved by using urea together with additional $\mathrm{NaOH}$ ). After synthesis, the suspended solids were filtered, washed thoroughly with demineralized water and dried at $130{ }^{\circ} \mathrm{C}$ before characterization. Some of the prepared saponites were exchanged with $\mathrm{Na}^{+}$, $\mathrm{NH}_{4}{ }^{+}$or $\mathrm{Al}^{3+}$ by suspending and stirring in $1 \mathrm{M} \mathrm{NaCl}, \mathrm{NH} 4 \mathrm{Cl}$, or $\mathrm{AlCl}_{3}$ overnight. [27]

Similarly, gels with $5.67(\mathrm{x}=1.2)$ or $7.89(\mathrm{x}=0.9) \mathrm{Si} / \mathrm{Ga}$ molar ratio and with $\mathrm{Mg}^{2+}$ or $\mathrm{Zn}^{2+}$ as the octahedral cation were prepared [45]. $\mathrm{Ga}(\mathrm{OH})_{4}^{-}$(from $\mathrm{GaCl}_{3}$ in $\mathrm{NaOH}$ solution) was added gradually 
while stirring continuously to a diluted $\mathrm{Na}_{2} \mathrm{SiO}_{3}$ solution $\left(27 \mathrm{wt} . \% \mathrm{SiO}_{2}\right)$ to form the gel. B-containing saponites were also synthesized using the gel method and an "aerosil" method. The latter method involved mixing aerosil from Degussa with borax $\left(\mathrm{Na}_{2} \mathrm{~B}_{4} \mathrm{O}_{7}\right)$ at a corresponding $\mathrm{Si} / \mathrm{B}$ molar ratio of 2.9-12.3 in demineralized water. As in previous synthesis, the mixtures were heated to $90{ }^{\circ} \mathrm{C}$, then added with the required amount of $\mathrm{Mg}\left(\mathrm{NO}_{3}\right)_{2} .6 \mathrm{H}_{2} \mathrm{O}$ or $\mathrm{Zn}\left(\mathrm{NO}_{3}\right)_{2} .4 \mathrm{H}_{2} \mathrm{O}$, together with $\mathrm{Na}\left(\mathrm{NO}_{3}\right)$ and urea. The influence of $\mathrm{pH}$ on saponite formation was studied by performing the synthesis at a starting $\mathrm{pH}$ level of about 8 and of about 3 (achieved by adjusting with concentrated $\mathrm{HNO}_{3}$ ). The temperature was kept at $90^{\circ} \mathrm{C}$ for the whole synthesis duration $(20 \mathrm{~h})$. The products were then filtered, washed thoroughly with demineralized water and dried overnight at $130{ }^{\circ} \mathrm{C}$ before further analyses. [45]

The method by Vogels at al. [27], which separates the synthesis into two steps - 1) formation of the precursor aluminosilicate gel and 2) hydrolysis of the divalent metal by the slow release of ammonia from the decomposition of synthesis urea - is a reasonable analog of natural processes. The aluminosilicate gels in the first step forms a 4 -fold-coordinated $\mathrm{Al}^{+3}$ similar to what is found in nature such as in volcanic glass. The use of urea, a compound figuring in many prebiotic model reactions, circumvents the formation of brucite, $\mathrm{Mg}(\mathrm{OH})_{2}$, in the final saponite product by slowly releasing ammonia thereby controlling the hydrolysis of magnesium [46]. This enables the formation of saponite without the accompanying sudden increase in $\mathrm{pH}$ which would have precipitated brucite [40].

Research studies making use of the thermal decomposition of urea as a means to control the $\mathrm{pH}$ during the synthesis of saponites include those of Besselink et al. [40], Prihod'ko et al. [47], Sychev and Prihod'ko [37], Xue and Pinnavaia [38] and Yu et al. [48]. Given that urea has more potential than just controlling the $\mathrm{pH}$ in clay mineral synthesis as it is a potential precursor of nucleobases and related molecules and a promoter of phosphorylation [25,26,49], the urea-assisted synthesis of saponites might be useful as starting point in extending research into urea assisting the synthesis of clay minerals while at the same time providing a source of precursors for nucleobases formation.

\subsection{Characterization of synthetic saponites}

Routine characterization techniques for saponites include X-ray Diffraction (XRD), X-ray fluorescence (XRF), Fourier Transform Infrared Spectroscopy (FTIR), magic-angle spinning-nuclear magnetic resonance (MAS-NMR), extended X-ray absorption fine structure spectroscopy (EXAFS) and pore and surface area analysis, thermogravimetric analysis and transmission electron microscopy (TEM). This section discusses how the group of Vogels et al. $[27,44,45,50]$ used these techniques to determine the structure of synthetic saponites and the changes they undergo as they interact with their environment.

\subsubsection{Powder X-ray diffraction (XRD)}

Although quantitative analysis of clay minerals using XRD remains challenging due to the various chemical compositions, preferred orientation, structural disorder and great structural diversity of clay minerals, it remains one of the most important analytical approaches used in the qualitative study of clay samples [51]. Typically, diffraction patterns of randomly oriented powder samples of the synthesis products are obtained with a diffractometer using $\mathrm{CuK} \alpha$ or $\mathrm{CoK} \alpha$ radiation, with alumina as a standard. 


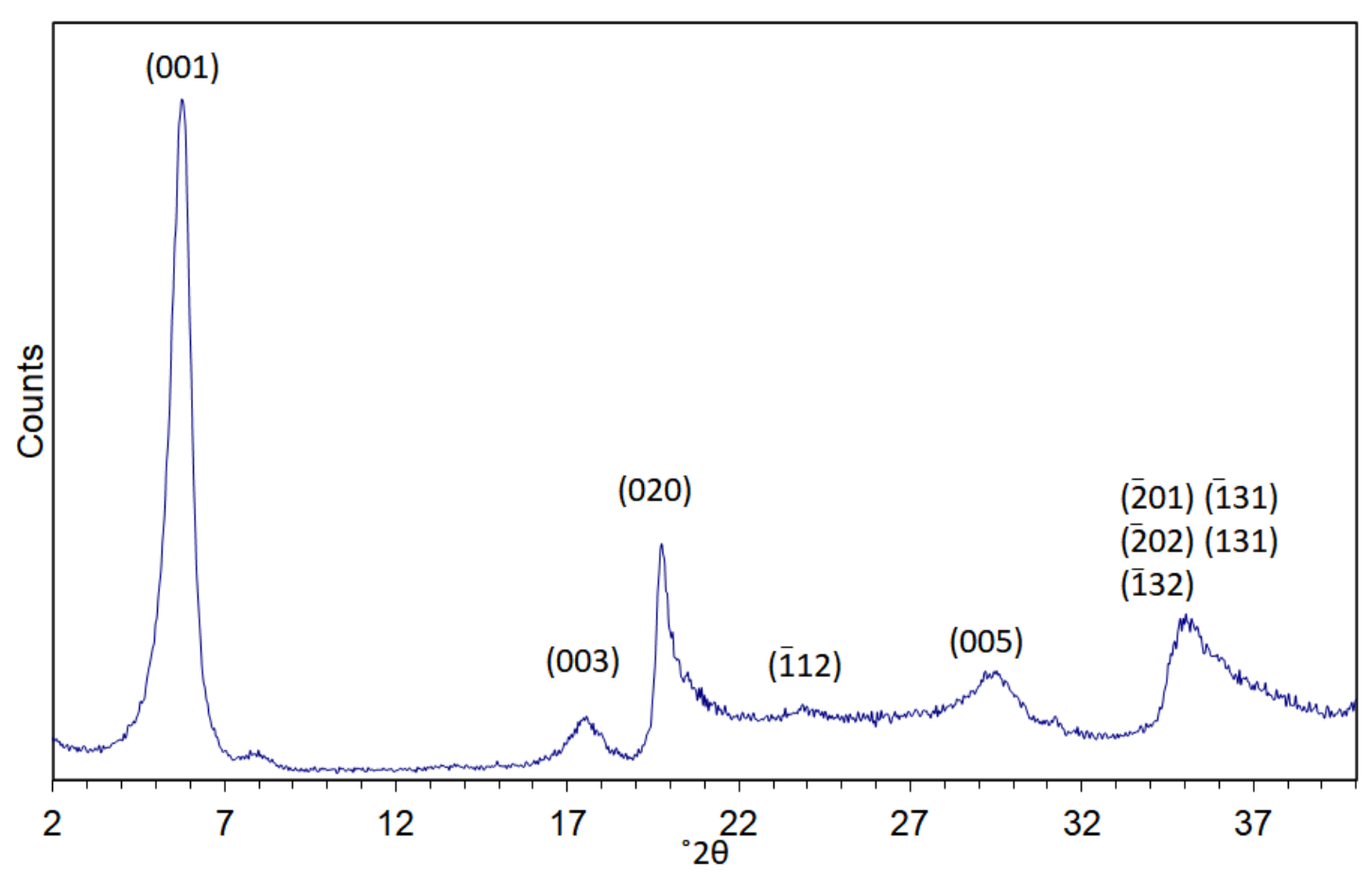

Figure 2. Typical X-ray diffraction pattern of a synthetic Zn-saponite synthesized for $20 \mathrm{hrs}$ with $72.1 \mathrm{~g}$ urea. Based on data from [27]. Note: no vertical axis was given in the original publication.

XRD was used to follow the crystallization and aging of Mg- and Zn-saponites [27]. The XRD profile of Zn-saponite is shown in Figure 1, for the complete set of XRD patterns, the reader is directed to [27]. The intensities of the (001) reflections of the synthetic saponites increased strongly and sharpened during aging. This points to a higher degree of stacking of the saponite layers. The dspacing of the (001) reflections decreases slightly from 13.2 to $12.7 \AA$. This was attributed to either an increase in particle size as larger particle size results in an increasing resistance to expansion, or a consequence of the interaction between the Lorentz-polarization (Lp) factor and the inference function. An intensity increase of the Lp factor with decreasing angle would result in a shift to lower angles of the maximum of broad peaks. From the XRD measurements, it was inferred that within 3 $\mathrm{h}$, the reaction of $\mathrm{Mg}$-saponite proceeded to a substantial extent resulting in platelets (length 5-10 nm as observed by TEM) without stacking. Longer synthesis times such as at 20 and 47 hours, the Mgsaponite particles formed still consisted of small platelets $(15-25 \mathrm{~nm})$ with a low extent of stacking ( 1-4 layers). This was consistent with observed preferential growth in the $a-b$ direction of the Mgsmectites prepared at low temperatures [52]. Saponites having a single type of metal ion within the octahedral sheets show XRD patterns with similar positions of the reflections except for differences in the position of the (001) reflections - $15.7 \AA$ for $\mathrm{Mg}, 14.7 \AA$ for Ni, $14.0 \AA$ for Co and $12.7 \AA$ for $\mathrm{Zn}$. The different $\mathrm{d}$-value of the (001) reflection is probably a result of particle size effects, although the effect of the presence of the divalent cations within the interlayer could not be ruled out. XRD also revealed that synthesis of $\mathrm{Cu}$-saponite was not successful; chrysocolla $\left[\mathrm{Cu}_{2} \mathrm{Si}_{2} \mathrm{O}_{5}(\mathrm{OH})_{2}\right]$ was formed instead [27,52]. Variation in the $\mathrm{Si} / \mathrm{Al}$ ratio from 5.67 to 39.0 was reported to have little effect on the XRD patterns. The very sharp XRD (001) reflection recorded for $\mathrm{Zn}$-saponite suggests the presence of relatively large and crystalline saponite crystals. In contrast, $\mathrm{Mg}-, \mathrm{Co}-$, and $\mathrm{Ni}$ - saponite were formed in smaller sizes than those of $\mathrm{Zn}$-saponites as revealed by the very broad (06l) reflections. This was corroborated by the reported TEM results. [27]

XRD was also used to follow the swelling behavior of the synthetic saponites by ethylene glycol (EG) vapor equilibration at $50{ }^{\circ} \mathrm{C}$ for 4 to 6 days prior to XRD measurements. Only the Mgand $\mathrm{Zn}$-saponites were explored in $[27,45]$. Results reveal the ability of the saponites to swell. $\mathrm{Na}^{+}-$ exchanged $\mathrm{Zn}$-saponite containing $\mathrm{Al}^{3+}$ in the tetrahedral sheet exhibited a d(001) value of $12.7 \AA$, roughly similar to those containing $\mathrm{Ga}^{3+}$. Treating the saponites with EG increased the $\mathrm{d}(001)$ spacing to $14.8 \AA . \mathrm{Ga}^{3+}$ containing Mg-saponite ( $\mathrm{Na}^{+}$-exchanged) exhibited d(001) spacing of $16.0 \AA$ which 
increased to $16.5 \AA$ after EG treatment. Determination of the interlayer space in swelling clays is important as it would provide information on what type and size of guest molecules that can be accommodated.

\subsubsection{Infrared spectroscopy (IR)}

Infrared (IR) spectroscopic techniques have long been established for the study of the clay mineral frameworks and of molecules adsorbed on their surfaces [53]. In addition, it has been applied to study the formation of clay minerals during synthesis [54]. In the studies by Vogels et al. [27,31] IR spectroscopy was typically performed using an IR spectrometer equipped with an in situ diffuse reflectance infrared Fourier transform (DRIFT) accessory. The samples were normally diluted with dry $\mathrm{KBr}$ (approx. 5 mass\% sample) and ground in a mortar and the measurements performed at room temperature. All spectra were generally recorded by accumulating 256 scans with a resolution of 4 $\mathrm{cm}^{-1}$ unless longer scans were necessary. The obtained spectra were ratioed against background vibrations and corrected for $\mathrm{KBr}$ absorption. The spectra of natural saponites (e.g., from Krugersdorp, Transvaal) (compiled by H.W. Van der Marel and H. Beutelspacher in Atlas of Infrared Spectroscopy of Clay Minerals and Their Admixtures [55] and cited by Kloprogge et al. [56]) revealed bands at 3675 (Mg-O-H), 3625 (Al-O-H), 3420 (H-O-H), 1630 (H-O-H), 1103 (Si-O), 1058 (Si-O/(Si-O-Si), 1005 (Si-O-Al), 750 (Si-O-Al), 693 (S-O-Mg), 652 (Mg-OH), 610 (Si-O), 528 ( $\mathrm{Si}-\mathrm{O}-\mathrm{Al} / \mathrm{Mg}), 480$ (Si-O), $462(\mathrm{Si}-\mathrm{O}-\mathrm{Mg})$ and $449 \mathrm{~cm}^{-1}(\mathrm{Si}-\mathrm{O}-\mathrm{Mg})$. The spectra of the synthetic saponites (Figure 3) described by Kloprogge et al. $[28,56]$ agreed well with the values observed for the natural saponite from Krugersdorp, although some $\mathrm{Si} \square \mathrm{O}$ vibrations were very weak or even absent. Upon exchanging the interlayer cation for $\mathrm{NH}_{4}{ }^{+}$a distinct additional band became visible at $1430 \mathrm{~cm}^{-1}$, in agreement with the findings of Kloprogge et al. [13] for synthetic ammonium-saponite. All other types of interlayer cations as well as the Si/Al ratio (5.67 to 39.0) did not affect the IR spectra. Ni-saponites exhibited one additional sharp absorption band at $2183 \mathrm{~cm}^{-1}$ which was assigned to an antisymmetric stretching vibration of $\mathrm{N}=\mathrm{C}=\mathrm{O}$ groups. Apparently, some isocyanate, which is an intermediate product during the hydrolysis of urea, had bonded to $\mathrm{Ni}^{2+}-\mathrm{OH}$ through a hydrogen bond, possibly by adsorption at the edge of the saponite octahedral sheet. After ion exchange with $\mathrm{NH}_{4}{ }^{+}$, Ni-saponite hardly exhibited an absorption band corresponding to (interlayer) $\mathrm{NH}_{4}{ }^{+}$, indicating a very low layer charge. The absorption bands of other $\mathrm{NH}_{4}{ }^{+}$exchanged saponites with similar $\mathrm{Si} / \mathrm{Al}$ ratios all showed an intense and sharp band around $1430 \mathrm{~cm}^{-1}$ indicating higher layer charges. The very low layer charge of Nisaponite was explained by substitution of $\mathrm{Ni}^{2+}$ by $\mathrm{Al}^{3+}$ in the octahedral sheet. The charge deficiency caused by the isomorphous substitution in the tetrahedral sheet was probably almost completely compensated by the octahedral substitution, because a high fraction of the $\mathrm{Al}^{3+}$ was incorporated in the octahedral sheet. Zn-saponites exhibit an opposite behavior compared to Ni-saponites. The intensity of the $\mathrm{NH}_{4}{ }^{+}$absorption band increased with the amount of $\mathrm{Al}^{3+}$, even when an "excess" amount of $\mathrm{Al}^{3+}$ was used $(\mathrm{Si} / \mathrm{Al}=2.33)$. Even though a higher amount of $\mathrm{Al}^{3+}$ resulted in an increasing percentage of six-fold coordinated $\mathrm{Al}^{3+}$ in the octahedral sheet (up to $40 \%$ for $\mathrm{Si} / \mathrm{Al}=2.33$ ), the layer charge seemed to increase, which favored the (muscovite) substitution $3 \mathrm{Mg}^{2+} \leftrightarrow 2 \mathrm{Al}^{3+}+$ vacancy, creating no positive charge on the octahedral sheet to compensate for the negative charge on the tetrahedral sheet [28]. 


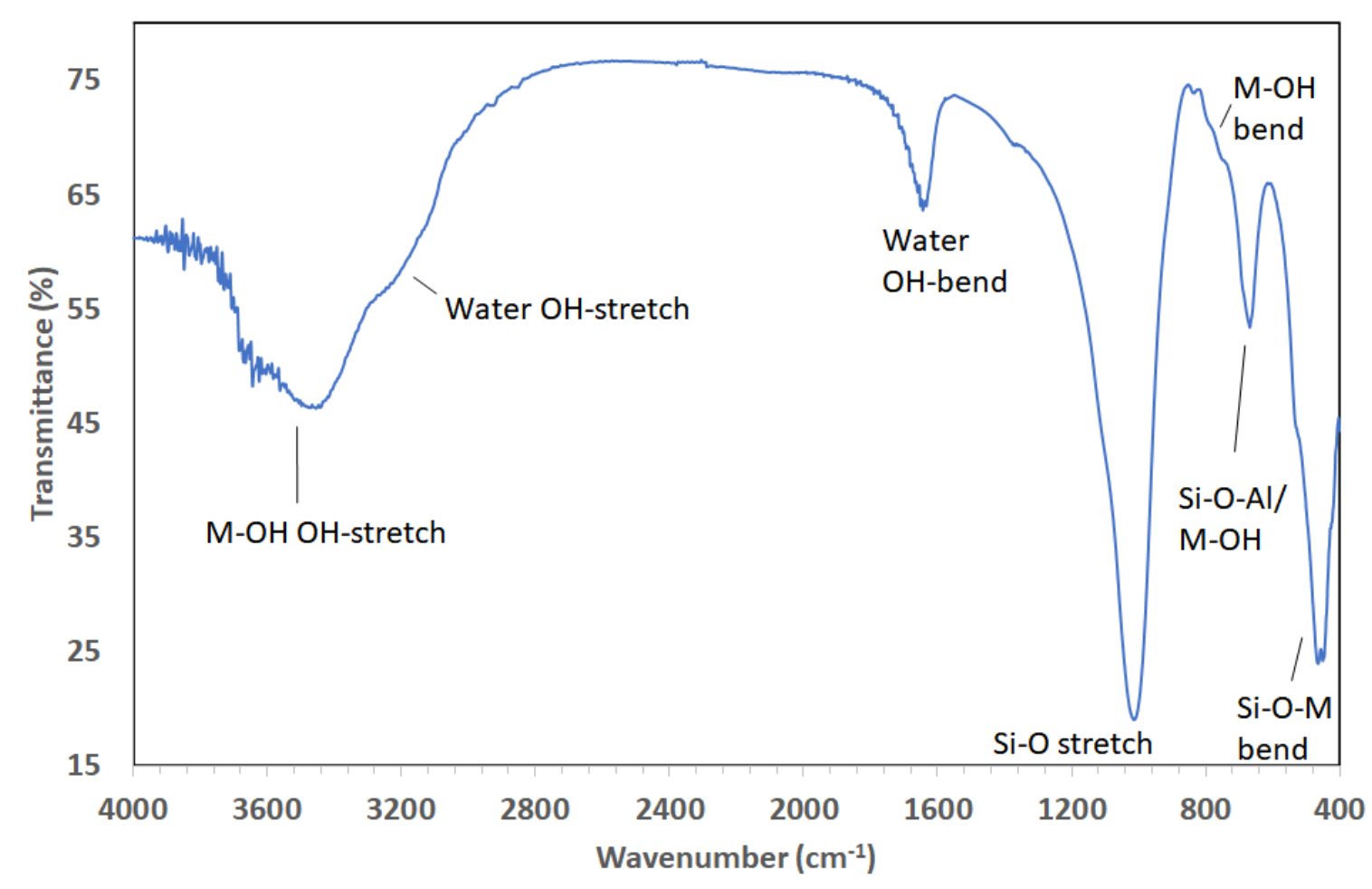

Figure 3. Typical IR spectrum of a synthetic Mg-saponite synthesized in 20 hours with $72.1 \mathrm{~g}$ urea. The IR spectrum was collected using a Perkin Elmer (1600 series) spectrometer in transmission mode using 256 scans at $4 \mathrm{~cm}^{-1}$ resolution using a $\mathrm{KBr}$ tablet (5 mass\% sample).

\subsubsection{Transmission electron microscopy (TEM)}

Electron microscopy (EM) including transmission electron microscopy (TEM) is one of the irreplaceable techniques for the investigation of clay minerals providing useful pieces of structural, physical, and chemical information (when equipped with energy or wavelength dispersive X-ray detector), which are not obtainable by other techniques. Typically, powdered samples are dispersed in ethanol ( $96 \mathrm{vol} \%)$ and ultrasonically treated for 5 minutes. A drop of the resulting suspension is then placed on a holey carbon film supported by a copper grid and the solvent evaporated. The samples were then investigated using a transmission electron microscope operated at an accelerating voltage of 100-200 kV. Coupled with energy-dispersive X-ray (EDX) analyzers, chemical analysis of samples can be performed. For example, an $\mathrm{Al}^{3+}$ exchanged $\mathrm{MgZn}$-saponite was analyzed to obtain information about the incorporation of both $\mathrm{Zn}^{2+}$ and $\mathrm{Mg}^{2+}$ in the clay structure [27,57]. The samples after 50 minutes of synthesis showed clusters of exceedingly small spherical particles typical of the starting $\mathrm{Zn}-\mathrm{Si} / \mathrm{Al}$ gel. TEM revealed that $\mathrm{Zn}$-saponite formed platelets (length $15 \mathrm{~nm}$ ) with little stacking in between the remaining gel particles after 1.5 hours of synthesis. After 12.25 hours, the synthesis was completed and clay platelets with a length of 100 to $200 \mathrm{~nm}$ consisting of stacks of about 10 layers were formed. Increasing synthesis hours to 22.75 hours resulted in particle ripening as indicated by a decrease in the number of particles but increase in particle size. [27,57]

\subsubsection{Magic-angle spinning-nuclear magnetic resonance (MAS-NMR) spectroscopy}

High resolution magic-angle spinning-nuclear magnetic resonance (MAS-NMR) spectroscopy of solids is a powerful tool for understanding the fine structure of clay minerals. For example, the precursor $\mathrm{Si} / \mathrm{Al}$ gel and the saponite products of the urea-assisted synthesis by Vogels et al. $[27,45]$ were characterized by ${ }^{27} \mathrm{Al}$ and ${ }^{29} \mathrm{Si}$ MAS-NMR spectroscopy. This allowed for the observation of the transformation of the $\mathrm{Si}$ and Al local environments. ${ }^{27} \mathrm{Al}$ MAS-NMR spectra were collected using the following parameters: $130.321 \mathrm{MHz}$ with a pulse length of $1 \mu \mathrm{s}$ and a pulse interval of 1 second while 
${ }^{29} \mathrm{Si}$ MAS-NMR spectra were collected at $99.364 \mathrm{MHz}$ with a pulse length of $6.5 \mu$ s and a pulse interval of 40 s. Chemical shifts $(\delta)$ of ${ }^{27} \mathrm{Al}$ and ${ }^{29} \mathrm{Si}$ were reported in ppm relative to $\left[\mathrm{Al}\left(\mathrm{H}_{2} \mathrm{O}\right)_{6}\right]^{3+}$ and $\left[\left(\mathrm{CH}_{3}\right)_{4} \mathrm{Si}\right]$, respectively.
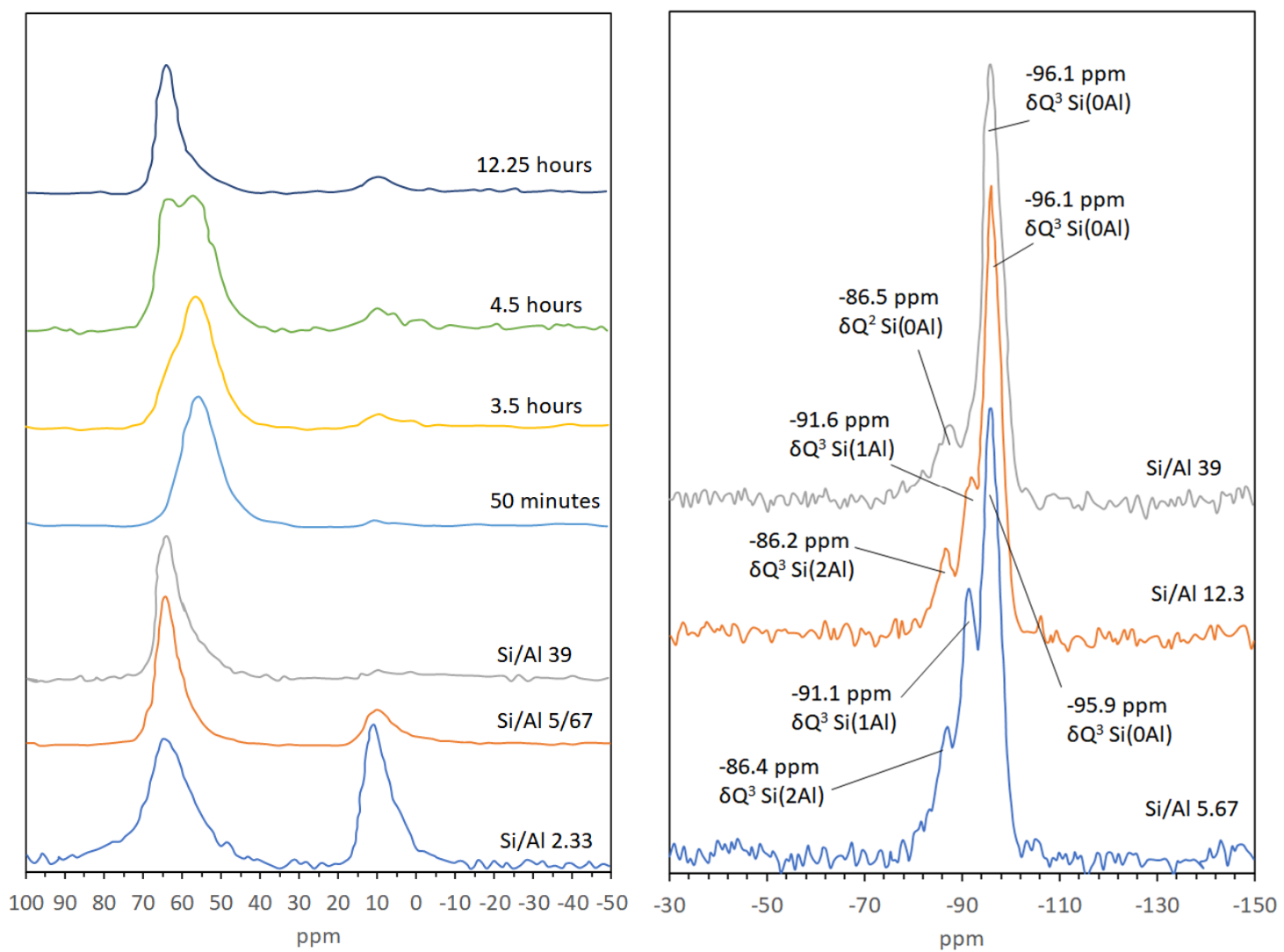

Figure 4. MAS-NMR of Zn-saponite with varying Si/Al ratio and varying synthesis time. ${ }^{27} \mathrm{Al}$ MASNMR (left) was performed at $130.321 \mathrm{MHz}$ with a pulse length of $1 \mu \mathrm{s}$ and a pulse interval of 1 second and chemical shifts $(\delta)$ reported in ppm relative to $\left[\mathrm{Al}\left(\mathrm{H}_{2} \mathrm{O}\right)_{6}\right]^{3+} .{ }^{29} \mathrm{Si}$ MAS-NMR (right) was performed at $99.364 \mathrm{MHz}$ with a pulse length of $6.5 \mu$ s and a pulse interval of $40 \mathrm{~s}$ and chemical shifts $(\delta)$ reported in ppm relative to $\left[\left(\mathrm{CH}_{3}\right)_{4} \mathrm{Si}\right]$. Modified from [27].

${ }^{27} \mathrm{Al}$ MAS-NMR confirmed that $\mathrm{Al}^{3+}$ in the $\mathrm{Si} / \mathrm{Al}$ gel is situated in fourfold coordination as reflected by a single resonance at approximately $56 \mathrm{ppm} .{ }^{27} \mathrm{Al}$ MAS-NMR was also used to follow the crystallization and aging of Zn-saponite (Figure 4) [27]. A broad band at $56 \mathrm{ppm}$ corresponding to the $\mathrm{Al}^{4}$ of the Si/Al gel was observed in the first 1.5 hours of synthesis. After $3.5 \mathrm{~h}$, some new resonances appeared next to the main gel resonance at $56 \mathrm{ppm}$. These resonances can be attributed to $\mathrm{Al}^{6}$ visible at about $9 \mathrm{ppm}$ together with an $\mathrm{Al}^{4}$ shoulder detectable at approximately $63 \mathrm{ppm}$ indicative of $\mathrm{Al}$ surrounded by three nearest-neighbor $\mathrm{Si}$ atoms. The signals most likely originated from the saponite structure. A further increase of the ageing time clearly resulted in the strong rise of the $\mathrm{Al}^{4}$ saponite resonance at $63 \mathrm{ppm}$ and a corresponding decrease of the $\mathrm{Al}^{4}$ peak of the Si/Al gel at $56 \mathrm{ppm}$. Also, the $\mathrm{Al}^{6}$ signal increased slightly during the first hours of the synthesis. ${ }^{27} \mathrm{Al}$ and ${ }^{29} \mathrm{Si}$ MAS-NMR experiments can also be performed to study in detail the effect of the $\mathrm{Si} / \mathrm{Al}$ ratio on the incorporation of $\mathrm{Al}^{3+}$ in the saponite structure. Lowering the amount of $\mathrm{Al}^{3+}$ clearly resulted in a decrease of the $\mathrm{Q}^{3} \mathrm{Si}(\mathrm{Al})$ resonance (i.e. a Si connected to $2 \mathrm{Si}$ and $1 \mathrm{Al}$ next nearest neighbors), and to a smaller extent of the $\mathrm{Q}^{3} \mathrm{Si}(2 \mathrm{Al})$ resonance ( $\mathrm{Si}$ connected to $1 \mathrm{Si}$ and $2 \mathrm{Al}$ ), as shown by the ${ }^{29} \mathrm{Si}$ MAS-NMR spectra of Zn-saponites prepared with Si/Al ratios of 12.3 and 39.0. The relatively high intensity of the resonance around about $-86 \mathrm{ppm}$ in saponites with a $\mathrm{Si} / \mathrm{Al}$ ratio of 39.0 is unlikely to be due to $\mathrm{Q}^{3} \mathrm{Si}(2 \mathrm{Al})$ taking into account the low amount of $\mathrm{Al}^{3+}$ and the nearly completely disappeared $\mathrm{Q}^{3} \mathrm{Si}(1 \mathrm{Al})$ resonance. A better explanation for the peak at $-86 \mathrm{ppm}$ is $\mathrm{Q}^{2} \mathrm{Si}(0 \mathrm{Al})$ present at the clay edges. The synthetic saponites are composed of exceedingly small particles with consequently a high amount of $\mathrm{Si}^{4+}$ situated at the clay edges. The fact that this $\mathrm{Q}^{2} \mathrm{Si}$ resonance in ${ }^{29} \mathrm{Si}$ 
MAS-NMR spectra of clay minerals is usually not observed in the literature can possibly be explained by the relatively large particle size of these (natural) samples compared to the synthetic saponite samples. [27]

In addition to saponite with different divalent metals on the octahedral position, saponites were synthesized in which tetrahedral metals were substituted by Ga and B [45]. Chemically gallium reacts similar to aluminum while boron can substitute for silicon. The XRD pattern of the Ga- and Bsubstituted saponites were similar to Al-substituted saponites. ${ }^{11} \mathrm{~B}$ MAS-NMR experiments were executed at $160.466 \mathrm{MHz}$ with a pulse length of $0.8 \mu \mathrm{s}$ and a pulse interval of $0.25 \mathrm{~s} .{ }^{71} \mathrm{Ga}$ MAS-NMR experiments were performed at $152.531 \mathrm{MHz}$ with a pulse length of $2.0 \mu \mathrm{s}$ and a pulse interval of 0.5 s. Chemical shifts $(\delta)$ of ${ }^{11} \mathrm{~B}$ and ${ }^{71} \mathrm{Ga}$ were reported in ppm relative to $\left[\mathrm{BF}_{3}\left(\mathrm{OEt}_{2}\right)\right]$ and $\left[\mathrm{Ga}\left(\mathrm{H}_{2} \mathrm{O}\right)_{6}\right]^{3+}$, respectively [45].

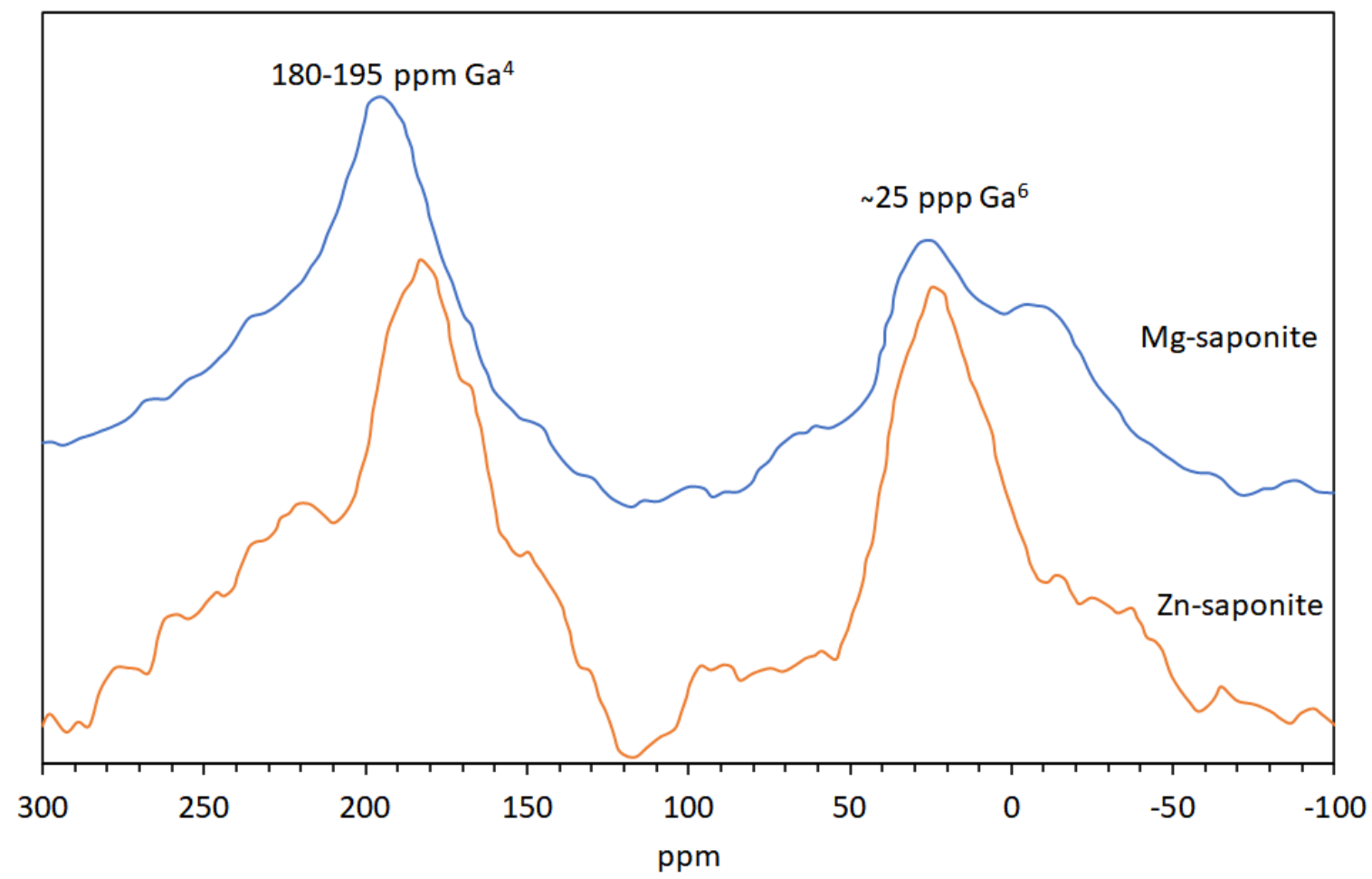

Figure 5. ${ }^{71} \mathrm{Ga}$ MAS-NMR of gallium substituted Mg- and Zn-saponite performed at $152.531 \mathrm{MHz}$ with a pulse length of $2.0\lceil\mathrm{~s}$ and a pulse interval of $0.5 \mathrm{~s}$ and chemical shifts $(\delta)$ reported in ppm relative to $\left[\mathrm{Ga}\left(\mathrm{H}_{2} \mathrm{O}\right)_{6}\right]^{3+}$. Modified from [45].

The ${ }^{71}$ Ga MAS-NMR spectra (Fig. 5) of $\mathrm{Ga}^{3+}$ containing Mg- and Zn-saponite exhibit two broad peaks at 25 and 180-195 ppm. As it is expected that like $\mathrm{Al}^{3+}, \mathrm{Ga}^{3+}$ can be found in both the tetrahedral $\left(\mathrm{Ge}^{4}\right)$ and octahedral $\left(\mathrm{Ge}^{6}\right)$ coordination sites of saponite, it would be reasonable to attribute the two broad peaks to $\mathrm{Ga}^{3+}$ in these positions with the lower chemical shift assigned to $\mathrm{Ga}^{6}$ [58]. The position of the $\mathrm{Ga}^{4}$ resonance of $\mathrm{Mg}$-saponite is about $10 \mathrm{ppm}$ more positive than that of the $\mathrm{Ga}^{4}$ resonance in $\mathrm{Zn}$-saponites. This is due to the higher ditrigonal rotation angle $\alpha$ in the tetrahedral sheets as a result of the smaller octahedral sheets in Mg-saponites. This is consistent with the observed shift to higher values of the peaks assigned to tetrahedral cations for related $\mathrm{Al}^{3+}$ containing 2:1 phyllosilicates when the rotation angle $\alpha$ increased [59]. 


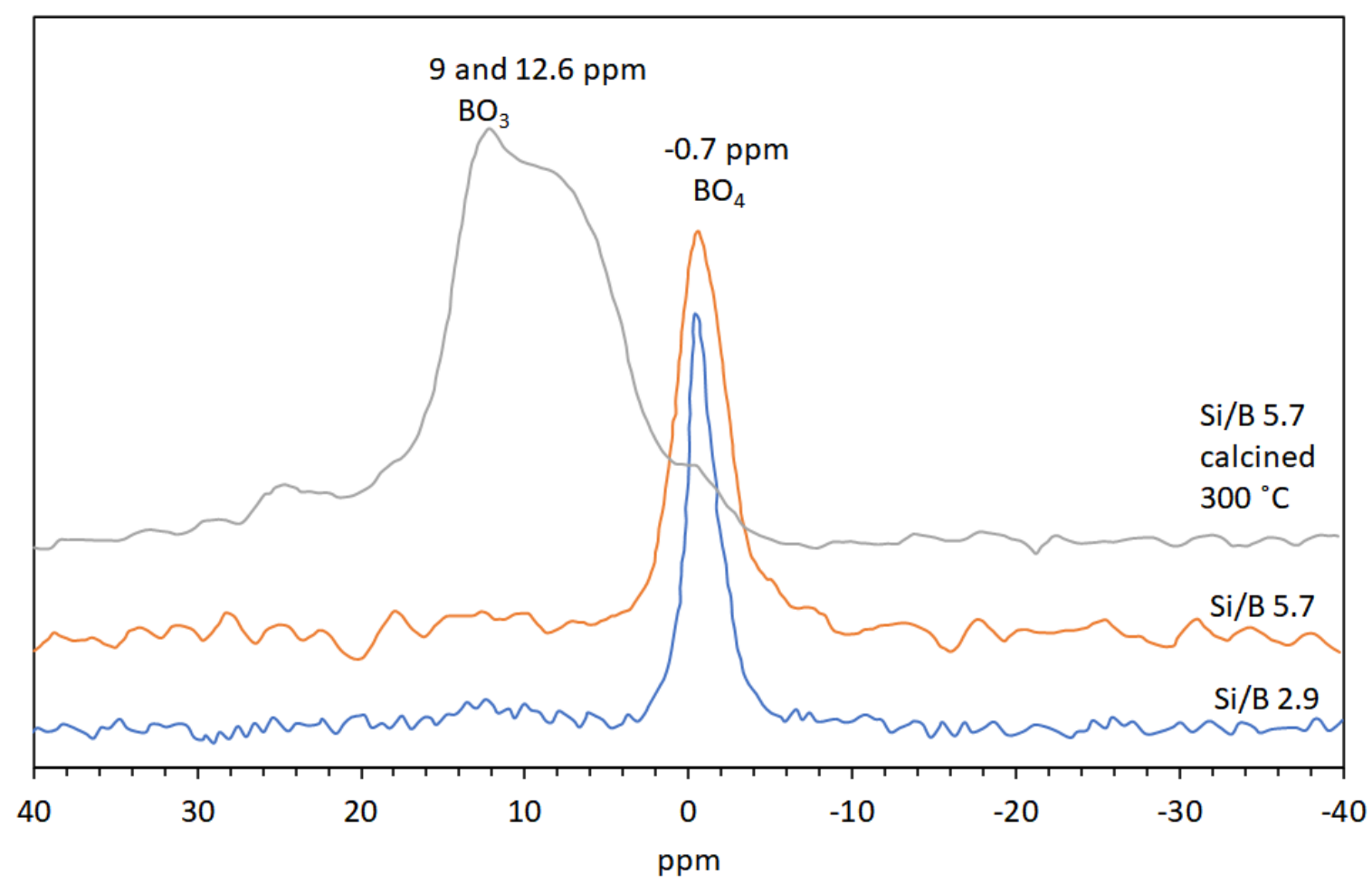

Figure 6. ${ }^{11} \mathrm{~B}$ MAS-NMR of Mg-saponite with different $\mathrm{Si} / \mathrm{Al}$ ratios and after calcination at $300{ }^{\circ} \mathrm{C} .{ }^{11} \mathrm{~B}$ MAS-NMR were run at $160.466 \mathrm{MHz}$ with a pulse length of 0.8 / $\mathrm{s}$ and a pulse interval of $0.25 \mathrm{~s}$ and chemical shifts in ppm relative to $\left[\mathrm{BF}_{3}(\mathrm{OEt})_{2}\right]$. Modified from [41].

${ }^{11} \mathrm{~B}$ MAS-NMR typically shows the resonance from trigonal $\mathrm{B}^{3+}\left(\mathrm{BO}_{3}\right)$ at around 19ppm and tetrahedrally coordinated $\mathrm{B}^{3+}\left(\mathrm{BO}_{4}\right)$ at about $2 \mathrm{ppm}$ [60]. Quadrupole coupling differences results in $\mathrm{BO}_{3}$ units usually appearing as broad doublets, whereas $\mathrm{BO}_{4}$ peaks are sharp [61]. A shift to a higher field of the $\mathrm{BO}_{4}$ peak has been shown to be a result of boron cations within silicate lattices. For example, the $\mathrm{BO}_{4}$ peak for danburite $\left(\mathrm{CaB}_{2} \mathrm{Si}_{2} \mathrm{O}_{8}\right)$, $\mathrm{B}^{3+}$ containing alkali feldspar $\left(\mathrm{NaAlSi}_{3} \mathrm{O}_{8}\right)$ and $\mathrm{B}^{3+}$ in zeolites is at $\sim 0.7 \mathrm{ppm}, \sim 1.1$ and $\sim 2.5 \mathrm{ppm}$, and $\sim 3$ to $\sim 5 \mathrm{ppm}$, respectively [60,62]. Vogels et al. [45] collected ${ }^{11} \mathrm{~B}$ MAS-NMR spectra of the $\mathrm{Si} / \mathrm{B}$ gels and showed that it only displayed a sharp signal at $\sim 1.7$ ppm consistent with $\mathrm{BO}_{4}$ coordinated with $\mathrm{SiO}_{4}$ tetrahedra. This NMR pattern of the $\mathrm{Si} / \mathrm{B}$ gel was not sensitive to hydration and drying effects as the signal at $\sim 1.7 \mathrm{ppm}$ for gels at $25^{\circ} \mathrm{C}$ shifted only slightly to $\sim 1.9 \mathrm{ppm}$ when the gels were calcined at $300^{\circ} \mathrm{C}$. Boron containing Mg-saponite synthesized from the gel with $\mathrm{Si} / \mathrm{B}$ molar ratio of 1.1 exhibited a broad peak of low intensity between 12.6 and 9.0 ppm and a sharp peak at $\sim 0.8 \mathrm{ppm}$. Mg-saponite with Si/B ratio of 2.9 and 5.7 exhibited only a sharp ${ }^{11} \mathrm{~B}$ MAS-NMR signal at $\sim 0.4$ and $\square 0.7$, respectively (see Figure 6). Albeit small, the shift of the $\mathrm{BO}_{4}$ signal of the synthetic saponite was significant as compared to the gel. This was taken as an indication of a successful incorporation of $\mathrm{B}^{3+}$ in the tetrahedral sheet of the saponite lattice. Calcination at 300 ${ }^{\circ} \mathrm{C}$ clearly showed the disappearance of the $\sim 0.7 \mathrm{ppm}$ signal and appearance of the broad peak between 9 and $12.6 \mathrm{ppm}$. This indicated the transformation from $\mathrm{BO}_{4}$ to $\mathrm{BO}_{3}$. Rehydrating the calcined saponite overnight at room temperature showed that the $\mathrm{B}^{3+}$ reverted back to tetrahedral coordination. This change in coordination of $\mathrm{B}^{3+}$ during dehydration/rehydration processes had been observed for B-containing boralite [63].

\subsubsection{Nitrogen physisorption measurements}

The role of clay minerals in the origin of life hinges on their ability to adsorb prebiotic molecules and subsequently catalyze their reactions into complex molecules. To understand the underlying mechanisms of these processes, the surface properties of clay minerals have to be precisely determined. Among the surface properties, the specific surface area (SSA) is a crucial parameter as it provides quantitative assessment of the areas available for surface reactions. The SSA of non-swelling 
and non-microporous clay minerals range from a fraction to more than $100 \mathrm{~m}^{2} / \mathrm{g}$. Higher values are obtained with microporous clay minerals and swelling (expanding) clay minerals [64].

Vogels et al. [27] obtained specific surface areas and (micro-) pore volumes (according to IUPAC conventions [65]) from nitrogen adsorption-desorption isotherms at $-196{ }^{\circ} \mathrm{C}$ using a surface area and porosimetry instrument. Adsorbent outgassing protocols were followed by exposing the powdered samples at temperatures around $130{ }^{\circ} \mathrm{C}$ under vacuum $[27,65]$. The total surface areas are calculated using the BET equation [66], and micropore surface areas are determined from t-plots, the external surface areas being the difference between the BET and micropore surface areas [67].
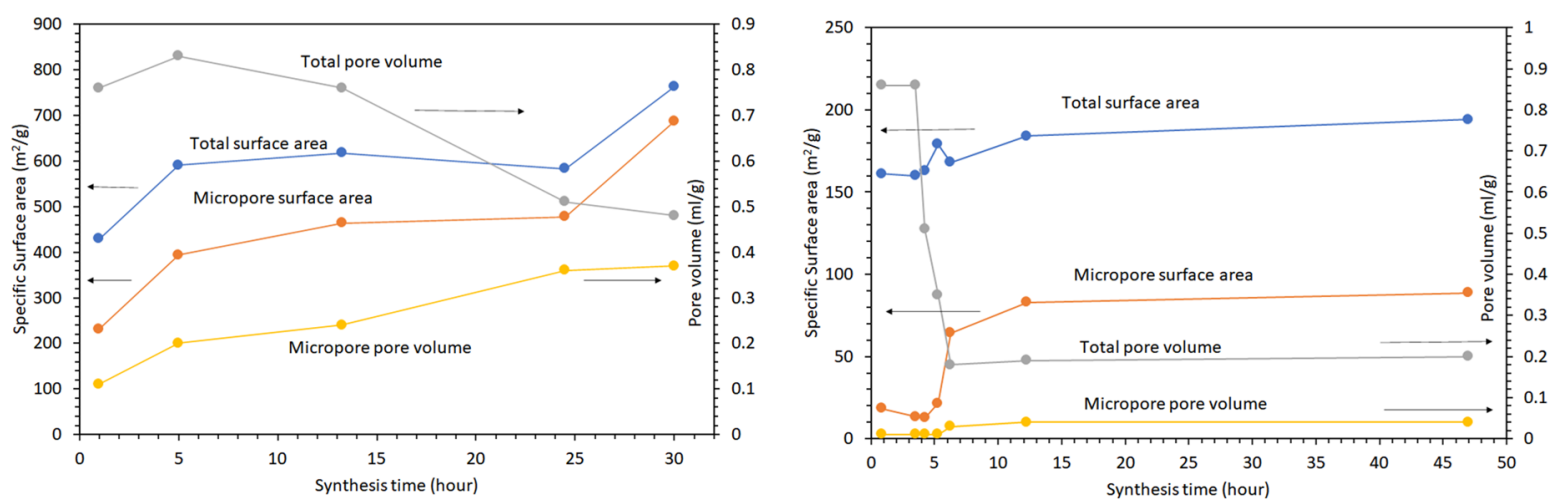

Figure 7. BET total and micropore surface area and pore volume of Mg- (left) and Zn-saponite (right) as function of synthesis time. These results are calculated based on Figure 5 in [27].

$\mathrm{N}_{2}$ adsorption-desorption isotherms for Mg-saponites synthesized for 5 to $30 \mathrm{~h}$ by Vogels et al. [27] were constructed and the BET total and micropore surface area and pore volume results are shown in Figure 7 (left). Synthesis for just $5 \mathrm{~h}$ exhibited an H1 type of hysteresis loop reflecting the gel matrix, similar to the gel matrix of Zn-saponite (vide infra) after 50 minutes preparation [27,65]. An H1 type of hysteresis is characterized by adsorption-desorption branches that are almost vertical and almost parallel over a wide range of gas uptake and is exhibited by materials with regular even pores with no interconnecting channels [65] such as MCM-41 (Mobil Composition of Matter No. 41) and SBA-15 (Santa Barbara Amorphous 15) [68]. Increasing the synthesis time to 24.5 hours produced Mgsaponite exhibiting a type H2(b) hysteresis loop in accordance with the 2015 updated IUPAC classification [65]. The H2 pattern in the 1985 IUPAC classification [69] is now labeled H2(a) [65]. It is characterized by a sloping adsorption branch and nearly vertical desorption branch. The steep desorption of the $\mathrm{H} 2$ (a) loop is associated with pore-blocking or percolation in a narrow range of pore necks. It can also be associated with cavitation-induced evaporation. Type H2(b) hysteresis loop is also associated with pore-blocking but the percolation is through a wider neck width distribution. This hysteresis pattern has also been observed in hydrothermally treated SBA-16 [70]. Further increasing synthesis time to 30 hours produced Mg-saponite powder that exhibited $\mathrm{H} 4$ type hysteresis loops which features an adsorption branch that resembles a composite of Types I and II isotherms and stays nearly horizontal over a wide $\mathrm{p} / \mathrm{p}^{\circ}$ range [65]. The $\mathrm{H} 4$ pattern is normally interpreted as due to filling of micropores and exhibited by micro- and mesoporous materials such as some zeolite foam series of Pt-catalyst supports [71] and in micro-mesoporous activated carbon [72]. The considerably higher amount of micropores noted for Mg-saponites in relation to $\mathrm{Zn}$ saponites synthesized by Vogels et al. [27] is suggested to be related to $\mathrm{pH}$ effects. This was argued based on the fact that after addition of the solution of bivalent metal ions some precipitation (of hydroxides) proceeded with $\mathrm{Ni}, \mathrm{Co}$, and $\mathrm{Zn}$ and a consequent decrease in $\mathrm{pH}$. Since the interaction and also the size of the elementary particles of a $\mathrm{M}^{2+} /$ silica/alumina suspension are strongly influenced by the $\mathrm{pH}$, the clustering and the size of the particles during the initial period of the synthesis will be, with the preparation of $\mathrm{Mg}$-saponite, different from that found with the synthesis of the other saponites [27]. For comparison, isotherms of $\mathrm{Zn}$-saponites with synthesis times of 0 to 3.5 hours were also constructed and the BET total and micropore surface area and pore volume results are shown in Figure 7 (right). As discussed above, the hysteresis loop of these specimens is of the H1 
type of the IUPAC classification. This pattern is typically found for agglomerations of porous materials with a narrow size distribution of cylinder-shaped mesopores. As with Mg-saponite (vide supra), longer synthesis times showed a distinct change from the $\mathrm{H} 1$ isotherm ( $3.5 \mathrm{hr}$ ) to the mainly $\mathrm{H} 4$ isotherms found for the saponites aged for at least 6.25 hours. This corroborated with their TEM observations of the Si/Al gel, which showed formation of clusters of very small spherical particles (after 50 minutes of synthesis) to formation of clay platelets which were 100-200 nm in lengths and stacked to about 10 layers [27]. The total surface area of Zn-saponites is $194 \mathrm{~m}^{2} / \mathrm{g}$ for samples synthesized for 47 hours, in contrast to the $763 \mathrm{~m}^{2} / \mathrm{g}$ total surface area of Mg-saponites synthesized for 30.0 hours [27]. A related saponite clay synthesized by Xue and Pinnavia in 2008 based on the methods of Vogels et al. [27] but using water glass as source of silica formed aggregates of irregularly stacked tactoids with a surface area of $920 \mathrm{~m}^{2} / \mathrm{g}$ [38]. A high surface area of a clay mineral can provide more adsorption sites and thus allow concentration of monomers and their subsequent polymerization. It is in this context that montmorillonite, an abundant swelling clay mineral, had been used as a model system for the adsorption and polymerization studies of organic molecules related to the origin of life $[4,6-8,13,21]$. However, most of these studies report an amount of adsorbed nucleotides (in mol) per gram of modified swelling clays and cannot be correlated with the total surface area of a clay mineral. It would be beneficial if quantities adsorbed are normalized to the specific surface areas of adsorbents as proposed by Pedreira-Segade et al. [73].

\subsubsection{X-ray fluorescence spectroscopy (XRF)}

$\mathrm{X}$-ray fluorescence (XRF) is normally used for routine, relatively non-destructive chemical analyses of rocks, minerals, sediments and fluids. The instrument works on wavelength-dispersive spectroscopic principles but is typically applied for analysis of bulk specimens. XRF involves easy and inexpensive sample preparation and when the stability and ease of use of X-ray spectrometers is added into consideration, XRF becomes one of the most widely used methods for analysis of major and trace elements in rocks, minerals, and sediment [74].

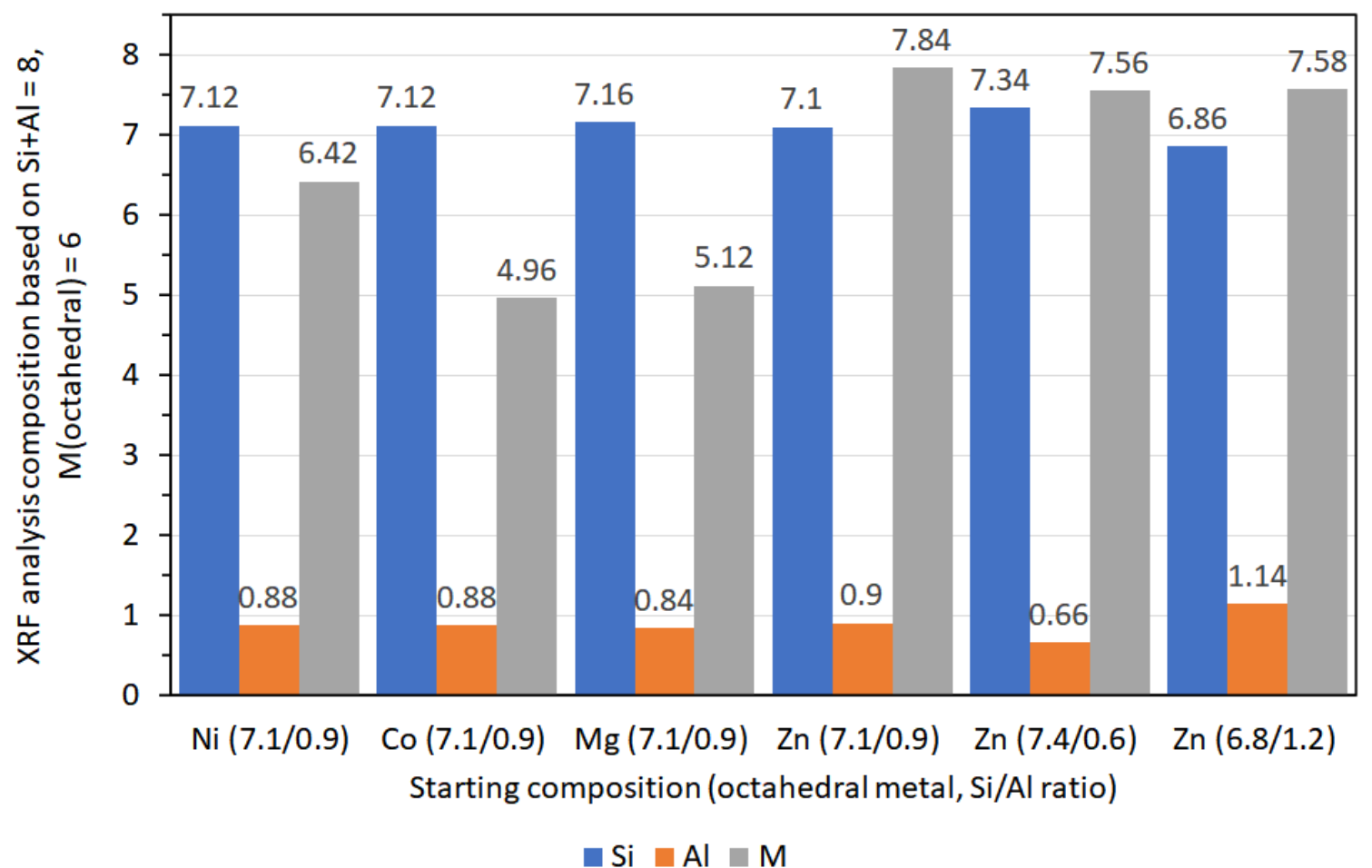

Figure 8. XRF analyses of different $\mathrm{M}$-saponites $(\mathrm{M}=\mathrm{Ni}, \mathrm{Co}, \mathrm{Mg}, \mathrm{Zn})$ and $\mathrm{Zn}$-saponite with different $\mathrm{Si} / \mathrm{Al}$ ratios. Results based on Table 5 of [24].

XRF measurements of saponite powdered samples were collected using an automated X-ray fluorescence spectrometer to obtain information about the bulk chemical composition of the samples. 
The XRF data of Vogels et al. [27], presented in molar ratios reflects good agreement of the Si/Al ratio of the resulting synthetic saponites with the intended $\mathrm{Si} / \mathrm{Al}$ ratio for all types of octahedral cations (Fig. 8). The experimentally determined fraction of octahedral cations slightly deviates from the theoretical value of $\mathrm{M}=6$ in $N_{x / z}^{z+}\left[\mathrm{M}_{6}\right]\left[\mathrm{Si}_{8}-\mathrm{A} \mathrm{Al}_{x}\right] \mathrm{O}_{20}(\mathrm{OH})_{4} \cdot \mathrm{nH}_{2} \mathrm{O}$. The lower octahedral cation concentrations for $\mathrm{Mg}$ - and Co-saponite (5.12 and 4.96, respectively) compared to the theoretical value of 6 is suggested to be due to incomplete crystallization with some gels remaining as observed with TEM for Mg-saponites. The incomplete crystallization for $\mathrm{Mg}^{2+}$ was rationalized in terms of solubility of $\mathrm{Mg}^{2+}$ at the final $\mathrm{pH}$ (around 7) after 20 hours of synthesis. Meanwhile, the low value for $\mathrm{Co}^{2+}$ concentration in Co-saponite had been argued as due to complexation of $\mathrm{Co}^{2+}$ with ammonia and some precipitation as $\mathrm{Co}(\mathrm{OH})_{2}$, the latter being observed with temperature-programmed reduction (TPR) experiments. As for the complexation of $\mathrm{Co}^{2+}$ with ammonia, this can occur in aqueous ammonia but the resulting $\left[\mathrm{Co}\left(\mathrm{NH}_{3}\right)_{6}\right]^{2+}$ is readily oxidized in this medium. The preferred ligand of $\mathrm{Co}^{2+}$ in this case, would be $\mathrm{H}_{2} \mathrm{O}$ while ammonia complexes preferentially with $\mathrm{Co}^{3+}$ [75]. The higher value of $\mathrm{Zn}$ - and $\mathrm{Ni}$-contents than theoretically calculated in $\mathrm{Zn}$ - and $\mathrm{Ni}$-saponites, on the other hand, were attributed to losses of the $\mathrm{Si} / \mathrm{Al}$ gel during the synthesis process [27]. Notwithstanding the slight deviations in resulting and expected values in chemical composition of the saponites reviewed in this section, XRF remains one of the routine analysis in following synthesis of clays and was used by Prihodko et al. [47] in determining agreement of chemical composition of $\mathrm{Mg}-$-, $\mathrm{Ni}$ - and $\mathrm{Co}$-saponite like materials and by Hongping et al. [76] in determining chemical composition of a series of synthetic saponites with varying $\mathrm{Si} / \mathrm{Al}$ ratios.

\subsubsection{Extended X-ray absorption fine structure spectroscopy (EXAFS)}

EXAFS is a popular nondestructive tool for the determination of local atomic structure in a variety of materials. It is the only spectroscopic technique that determines electronic and structural properties of catalysts under reaction conditions and in the presence of reactants [77]. In this section, the use of EXAFS by Vogels et al. [27] to probe the structures of $\mathrm{H}^{+-}$exchanged saponites with $\mathrm{Mg}^{2+}$, $\mathrm{Ni}^{2+}, \mathrm{Co}^{2+}$, or $\mathrm{Zn}^{2+}$ as octahedral cations is highlighted. The saponites are designated as HM-saponite where $\mathrm{M}$ is the octahedral metal cation (e.g. HNi-saponite). The EXAFS measurements were performed with a soft XAFS station 3.4 of the SRS facility at Daresbury, UK, which is equipped with a quartz double-crystal monochromator and collimating mirrors that minimize the harmonic contamination of the X-ray beam. EXAFS data at the Al K edge $(1559 \mathrm{eV})$ with a resolution of $1.5 \mathrm{eV}$ were simultaneously collected with a fluorescence detector. The spectra were collected in six scans averaged to minimize both high- and low-frequency noise. The authors collected their EXAFS data in fluorescence mode as the instrumental background in the EXAFS region of electron yield spectra was unreliable. The choice of reference compounds, experimental conditions and standard procedures for analysis of XAFS data followed the report of Koningsberger and Miller [78]. The latest version of a XAFS Data Analysis Program (XDAP) at the time of the study was used which allowed for fitting in r-space using both the imaginary and the absolute part of the Fourier transform. This would allow for reliable resolution of the two different Al-O coordination as the imaginary part is much more sensitive to the coordination distance as will be discussed later. Results presented in Vogels et al. [27] showed that for $\mathrm{Al}^{3+}$ in saponites, the position of the whiteline for tetrahedral $\mathrm{Al}$ is at $2 \mathrm{eV}$ and for octahedral $\mathrm{Al}$ is at $6 \mathrm{eV}$ beyond the edge which were sufficiently different that a clear distinction can be made between $\mathrm{Al}_{\text {tet }}$ and the Aloct. The authors have shown that the octahedral contribution decreases in the order $\mathrm{Ni}>\mathrm{Zn}>\mathrm{Mg}=\mathrm{Co}$. However, the intensity of the Altet whiteline did not increase in the same order. These results were interpreted based on XAFS studies of zeolites which have shown that an increasing whiteline intensity (i.e., increasing positive charge) is related to an increasing acid strength [79]. The EXAFS spectra showed marked differences in the imaginary parts of the Fourier transforms between 1.5 and $2.2 \AA$ and in the higher shells between 2.5 and $3.5 \AA$. These differences were attributed to different second-nearest neighbors ( $\mathrm{Ni}$ vs. $\mathrm{Mg}$ ). From the whiteline data, the authors deduced that both tetrahedrally and octahedrally coordinated $\mathrm{Al}^{3+}$ ions were present in the saponite samples. Moreover, information on Al-O coordination distances was reported to be in the range 1.65 to $1.74 \AA$ for Altet and 1.84 to $1.88 \AA$ for Aloct. These are typical for AlO coordination distances observed for $\mathrm{Y}$ zeolites [80] and clay minerals [81]. 
Apart from information on Al-O coordination and bond lengths as well as influence of second nearest neighbors as presented by Vogels et al. [27], EXAFS was used to determine interatomic distances and local environment of other clay minerals. For example, it was used to determine interatomic distances between octahedral cations, $\mathrm{Mg}, \mathrm{Al}$ and $\mathrm{Zn}$ with $\mathrm{O}$ in montmorillonite synthesized via fluorine route by Reinholdt et al. [82]. The group also used EXAFS to reveal: 1) strong local octahedral sheet distortions with respect to the ideal montmorillonite structure and 2) lengthening of the out-of-plane $\mathrm{Zn}-\mathrm{Si}(\mathrm{Al})$ distances indicating the swelling of the entire layer in the neighborhood of $\mathrm{Zn}$ [82].

\subsection{8 $\mathrm{pH}$ analysis}

The $\mathrm{pH}$ of the suspensions during saponite synthesis was followed using a $\mathrm{pH}$ meter such as a SchottGeräde pH-meter CG804 with electrodes from Ingold. Slurry pH measurement, cannot be neglected since it can affect the synthesis of saponites $[27,29,40,46,83]$. For example, Bahldermann et al. [84] observed that high initial slurry $\mathrm{pH}$ precipitated brucite, $\mathrm{Mg}(\mathrm{OH})_{2}$. This undesired formation of brucite was avoided saponite synthesis was performed in two steps: formation of an aluminosilicate gel at high $\mathrm{pH} \approx 13$; followed by a saponite formation between $\mathrm{pH} 7$ and 8 , aided by hydrolyzing urea $[27,46]$. The nucleation and growth of the saponite proceeds gradually, and no temporarily fast $\mathrm{OH}-$ consumption is exhibited. The initial $\mathrm{pH}$ decrease is probably a result of the possible formation of hydroxides. An observed large difference in initial $\mathrm{pH}$-levels recorded with the synthesis of $\mathrm{Mg}$ saponite, on one hand, and the $\mathrm{Zn}$-, Co-, or Ni-saponites, on the other, is due to the different solubilities of the corresponding hydroxides - Mg-hydroxide being significantly more soluble than $\mathrm{Ni}-, \mathrm{Co}^{-}$, and $\mathrm{Zn}$-hydroxides (Ksp values of the hydroxides are: $\mathrm{Mg}(\mathrm{OH})_{2}=5.61 \times 10^{-12} ; \mathrm{Ni}(\mathrm{OH})_{2}=5.48$ $x 10^{-16} ; \mathrm{Co}(\mathrm{OH})_{2}=5.92 \times 10^{-15} ;$ and $\left.\mathrm{Zn}(\mathrm{OH})_{2}=3.0 \times 10^{-17}\right)$.

\section{Thermal properties of saponites}

\subsection{Thermal stability}

The thermal stability of clay minerals is an important parameter to measure since most industrial applications involving heterogeneous catalysis take place at increased temperatures. Components of primitive atmosphere which are soluble in water would react to form various amino acids under hydrothermal conditions. This was shown plausible by Marshall [85] when he synthesized several amino acids and abundant amines from aqueous $\mathrm{NH}_{4} \mathrm{HCO}_{3}$ solutions and $\mathrm{C}_{2} \mathrm{H}_{2}, \mathrm{H}_{2}$, and $\mathrm{O}_{2}$ (formed in situ from $\mathrm{CaC}_{2}, \mathrm{Ca}$, and $\mathrm{H}_{2} \mathrm{O}_{2}$ ) at $200-275^{\circ} \mathrm{C}$. Moreover, some studies on the polymerization of glycine with clay minerals were reported under hydrothermal conditions $\left(5-100 \mathrm{MPa}, 150{ }^{\circ} \mathrm{C}\right)$ [86]. Therefore, it is important that the catalyst is stable at those temperatures. In the works of Vogels et al. [44], thermal stability was studied using thermal gravimetric analysis (TGA) and differential thermal analysis (DTA). The samples were typically ground thoroughly in air and subsequently calcined in air in a furnace with a constant heating rate of $5^{\circ} \mathrm{C} / \mathrm{min}$. Collection of thermograms were performed by placing samples in furnace at room temperature and then raising it to the desired calcination temperature, which ranged from 120 to $900{ }^{\circ} \mathrm{C}$, for 4 or 16 hours depending on the subsequent characterization techniques. 


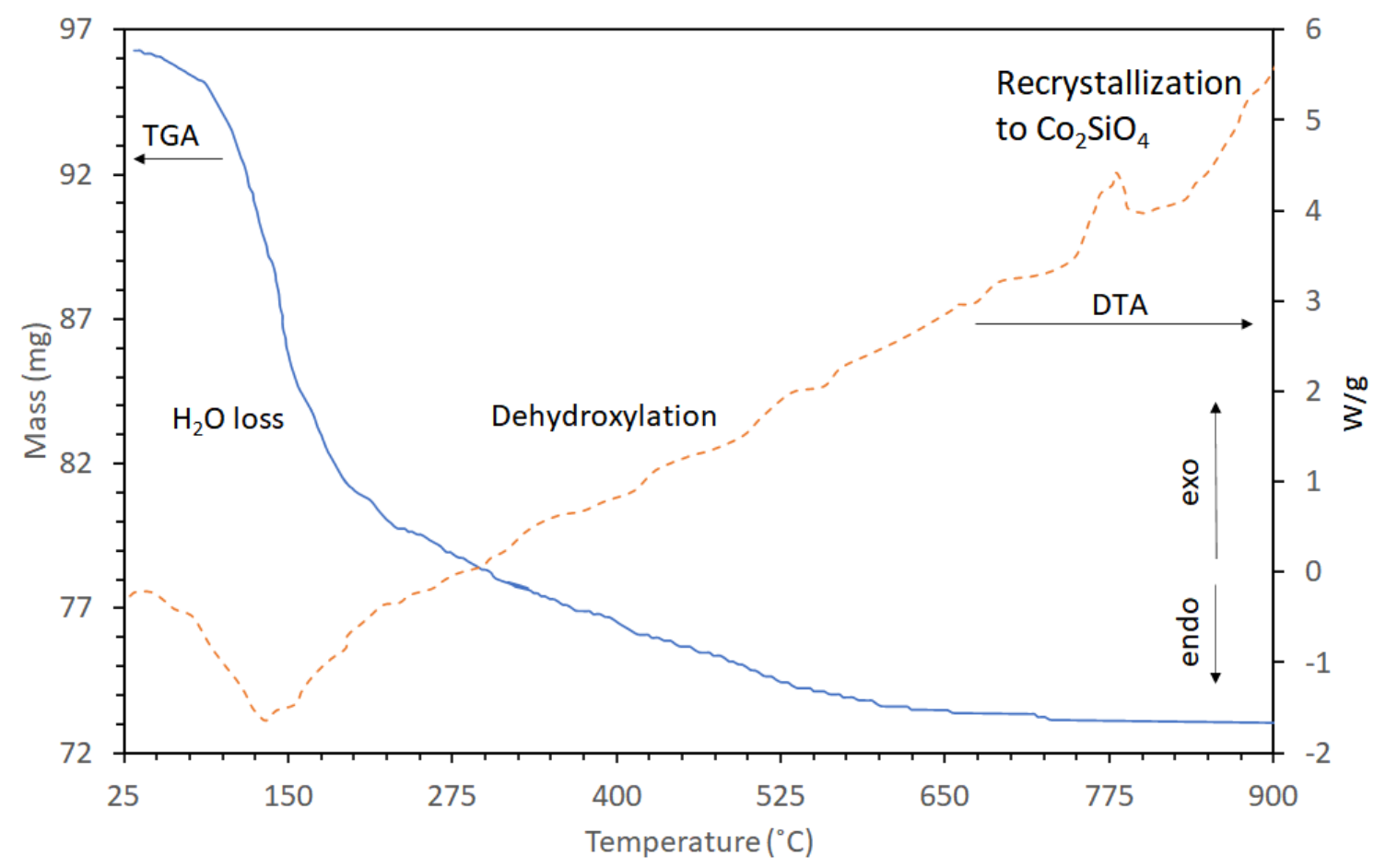

Figure 9. Thermogravimetric (TGA) and differential thermal analysis (DTA) of Co-saponite (Al ${ }^{3+}$ exchanged). Modified from Figure 1 [44].

The curves of mass loss and heat flow versus temperature of Co-saponite studied in [44] is shown in Figure 9. This is comparable to those of the different $\mathrm{M}^{2+}$-saponites in the same study. Removal of weakly bound water was exhibited by the sharp mass loss between room temperature and approximately $200{ }^{\circ} \mathrm{C}$ in the TGA curve and a corresponding endothermic peak in the DTA curve with a maximum at $130{ }^{\circ} \mathrm{C}$. Removal of the remaining strongly bound interlayer water occurred between 200 and roughly $400{ }^{\circ} \mathrm{C}$ and this was followed by the dehydroxylation of the saponite structure beyond approximately $400{ }^{\circ} \mathrm{C}$. No further mass loss was observed at higher temperatures. The dehydroxylation of the synthetic saponites of this study is characterized by a gradual mass loss and lacking an endothermic peak in the DTA curve. This pattern is different from the observed dehydroxylation of other saponites in which the TGA plot showed a second sharp mass loss at a temperature between 500 and $800{ }^{\circ} \mathrm{C}$ and an associated clear endothermic peak in the DTA curve [28]. Here, the DTA curve displayed a sharp exothermic maximum at $770{ }^{\circ} \mathrm{C}$ (Figure 9) corresponding to the rapid recrystallization of the Co-saponite into $\mathrm{Co}_{2} \mathrm{SiO}_{4}$. 


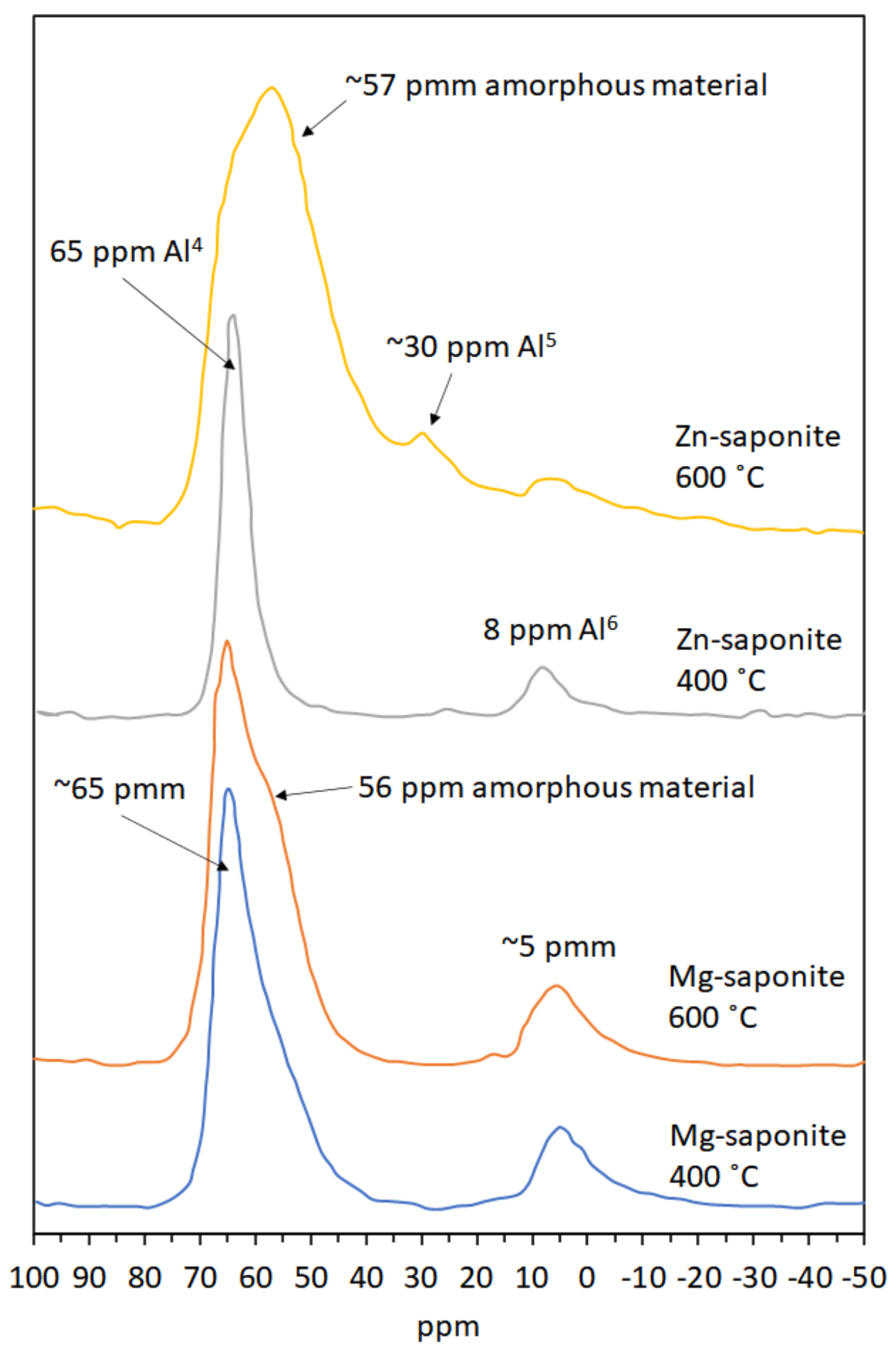

Figure 10. ${ }^{27} \mathrm{Al}$ MAS-NMR of Mg- and Zn-saponite thermally treated for 4 hours at 400 and $600{ }^{\circ} \mathrm{C}$. Redrawn from Figure 2 in [44].

To follow changes in the structure of synthetic saponites upon calcination, Vogel et al. [44] performed thermal analyses alongside MAS-NMR. Figure 10 shows ${ }^{27} \mathrm{Al}$ MAS-NMR results obtained with Mgand $\mathrm{Zn}$-saponite calcined at 400 and $600{ }^{\circ} \mathrm{C}$ for 4 hours, respectively. Spectra of fresh samples were not shown by the authors as there was no change in the MAS-NMR spectra of a fresh sample compared to a sample calcined at $400{ }^{\circ} \mathrm{C}$ for 4 hours. The six-fold $\left(\mathrm{Al}^{6}\right)$ and four-fold $\left(\mathrm{Al}^{4}\right)$ coordinated aluminum in the octahedral and tetrahedral sheets of the Mg-saponite lattice are centered 
respectively at approximately 5 and $65 \mathrm{ppm}$ in the ${ }^{27} \mathrm{Al}$ MAS-NMR spectra $[44,87]$. Increasing the calcination temperature to $600{ }^{\circ} \mathrm{C}$ resulted in the appearance of a shoulder at $56 \mathrm{ppm}$ on the low-field side of the $\mathrm{Al}^{4}$ saponite resonance, which was interpreted as $\mathrm{Al}^{4}$ present in amorphous material. Similarly, the $\mathrm{Al}^{6}$ and $\mathrm{Al}^{4}$ coordinated aluminum in $\mathrm{Zn}$-saponite calcined at $400{ }^{\circ} \mathrm{C}$ are centered at about 8 and $64 \mathrm{ppm}$ in the ${ }^{27} \mathrm{Al}$ MAS-NMR spectra. However, increasing the calcination temperature to $600{ }^{\circ} \mathrm{C}$ destroyed the structure of $\mathrm{Zn}$-saponite. This was according to the ${ }^{27} \mathrm{Al}$ MAS-NMR results where a large $\mathrm{Al}^{4}$ resonance at $57 \mathrm{ppm}$ together with a fivefold coordinated aluminum resonance at $30 \mathrm{ppm}$ were suggested to be derived from amorphous materials [88]. Indeed, their XRD results no longer showed crystalline species in the $\mathrm{Zn}$-saponite sample thermally treated at $600{ }^{\circ} \mathrm{C}$. The instability of $\mathrm{Zn}$-saponite compared with $\mathrm{Mg}$-saponite was rationalized based on the strong influence of the composition and the effective ionic radius of the cations in the octahedral sheet on the thermal stability. Hazen and Wones [89] explained that the size of the octahedral cation of trioctahedral micas affects the dimensions in the direction of the $b$-axis of the unit cell and, consequently, the lateral fit (achieved by contracting the tetrahedral sheet, thereby introducing a tetrahedral layer rotation over the angle $\alpha$ ) between the tetrahedral and the octahedral sheets. Using the works of Hazen and Wones [89] on trioctahedral micas, which are structurally analogous to saponites, as guide, Vogels et al. [44] reported the ionic radii of the octahedral cations $\mathrm{Ni}^{2+}, \mathrm{Mg}^{2+}, \mathrm{Co}^{2+}$, and $\mathrm{Zn}^{2+}$ present within phyllosilicates to be $0.69,0.72,0.74$, and $0.75 \AA$, respectively, and related this to the observed differences in stability of the saponites. The value of $\alpha$ is approximately $9^{\circ}$ for a relatively small octahedral cation, such as $\mathrm{Ni}^{2+}$. This value will decrease with an increase of the ionic radius eventually reaching $0^{\circ}$ when the octahedral cation is sufficiently large. Increasing further the size of the octahedral cation will result in an unstable system, since the tetrahedral sheet cannot adjust further by rotation. The limiting value of the ionic radius is approximately $0.76 \AA$ for $\alpha=0^{\circ}$; this is very close to the size of $\mathrm{Zn}^{2+}(0.75 \AA)$ in the octahedral sheet, hence, the purported reason for the instability of $\mathrm{Zn}$-saponite. Resistance against thermal decomposition is improved when a large cation is combined with a smaller cation in the octahedral sheet as was observed for MgZn-saponite, which was found to be more thermally stable than pure Zn-saponite [44].

Vogels et al. [44] also analyzed the development of the specific surface areas (SSA) and pore volumes of some thermally treated saponites (Figure 11). All the saponites calcined at temperatures above $450{ }^{\circ} \mathrm{C}$ suffered a partial collapse of the layered structures causing a decrease of the SSA values. Most notable was the decrease of the SSA of $\mathrm{Zn}$-saponite to almost zero at $600{ }^{\circ} \mathrm{C}$. This was attributed to the total breakdown of the layered structure to amorphous material as discussed (vide supra). The total and micro pore volumes of a Ni-saponite thermally treated at different temperatures show hardly any decrease up to $450{ }^{\circ} \mathrm{C}$ (Figure 11). As with SSA, the micropore volume decreased at higher temperatures. This was observed for the other saponites, except for $\mathrm{Zn}$-saponite, the total pore volume of which is zero after treatment at $600{ }^{\circ} \mathrm{C}$ [44]. Notwithstanding the observed collapse of saponites when treated to temperatures above $450{ }^{\circ} \mathrm{C}$, it is worth noting that the samples remain stable against thermal decomposition at temperatures $\left(200-275^{\circ} \mathrm{C}\right)$ used for hydrothermal synthesis of amino acids from reactants possibly present in primitive environments [85]. 


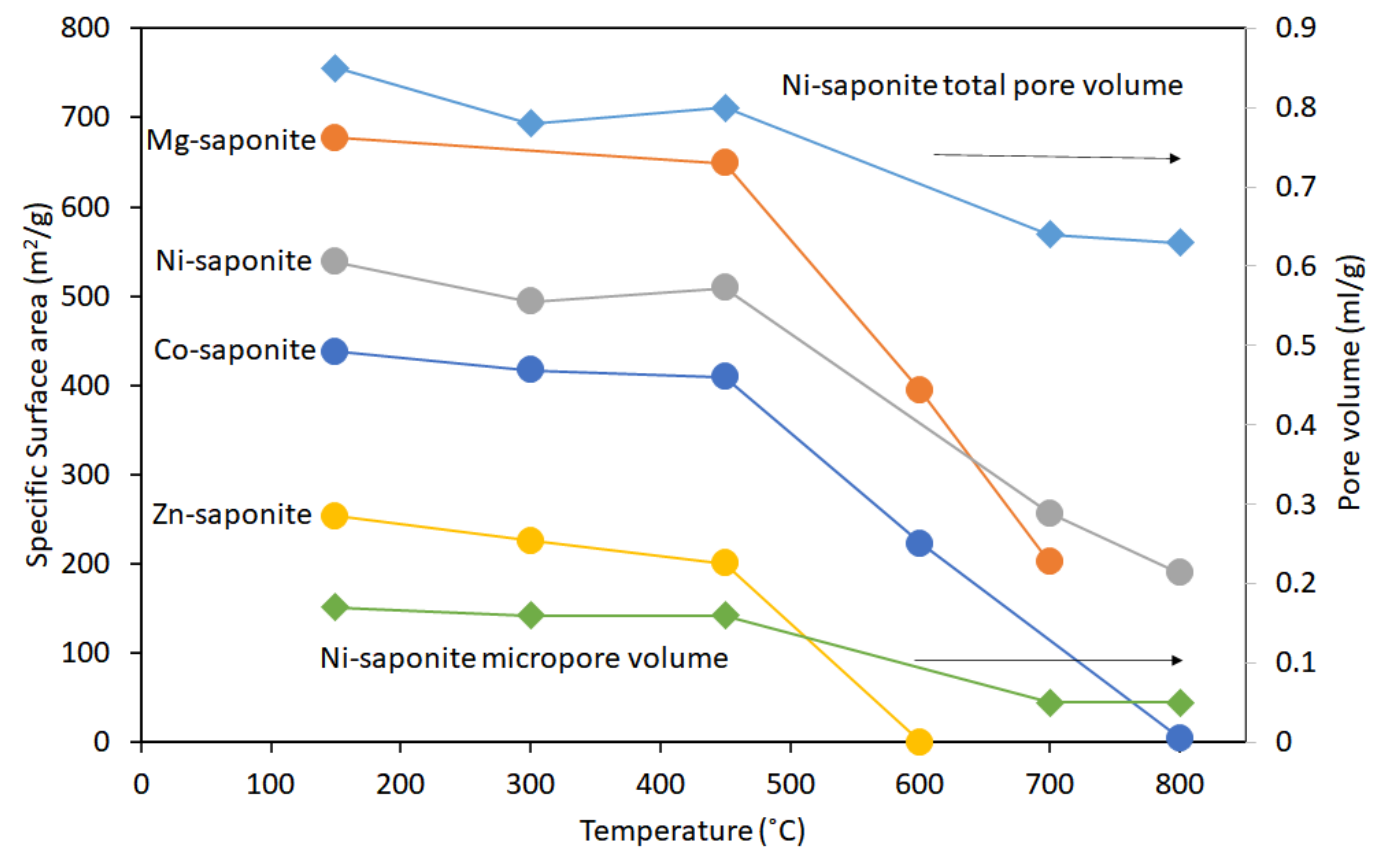

Figure 11. BET surface area and pore volume as function of calcination temperature of M-saponites $(\mathrm{M}=\mathrm{Mg}, \mathrm{Ni}, \mathrm{Co}, \mathrm{Zn})$. Modified from Figure 3 in [44].

\subsection{Hydrothermal stability}

Early sediments can react with hydrothermal water to form clay minerals. Moreover, clay minerals are known to occur at hydrothermal vents and provide important clues to understanding adsorptive synthesis of prebiotic molecules as only in their presence can certain chemical reactions occur [90]. In this featured work of Vogels et al. [44], hydrothermal stability studies are presented for synthetic Mg-saponite and a MgZn-saponite samples. Typically, $100 \mathrm{mg}$ amount of samples were placed in a quartz reactor, the temperature of which was raised linearly from room temperature to 400,500 , or $600^{\circ} \mathrm{C}$ at a rate of $5^{\circ} \mathrm{C} / \mathrm{min}$. At the same time, a $\mathrm{N}_{2}$ flow of $50 \mathrm{~mL} / \mathrm{min}$ was passed through the sample. When the desired temperature $\left(400,500\right.$, or $600{ }^{\circ} \mathrm{C}$ ) was reached, $30 \mathrm{vol} \% \mathrm{H}_{2} \mathrm{O}$ in $\mathrm{N}_{2}$ (obtained by passing the $\mathrm{N}_{2}$ flow through a saturator kept at $70^{\circ} \mathrm{C}$ ) was put through the sample for 4 or 16 hours. The two ${ }^{27} \mathrm{Al}$ MAS-NMR resonances at approximately 65 and $5 \mathrm{ppm}$, which were attributed to aluminum in tetrahedral $\left(\mathrm{Al}^{4}\right)$ and octahedral coordination $\left(\mathrm{Al}^{6}\right)$, respectively, remain visible without displaying a change in chemical shift, even after four hours at $600{ }^{\circ} \mathrm{C}$ in steam. This indicated the high stability of the clay structure with respect to hydrothermal treatment. XRD and MAS-NMR results revealed that steam had little effect on the hydrothermal stability of Mg-saponite but had significant effects on saponites which have $\mathrm{Zn}^{2+}$ incorporated in the octahedral sheets. Stability of saponites incorporating $\mathrm{Zn}^{2+}$ decreased. For example, saponites where $\mathrm{Mg} / \mathrm{Zn}$ is 2 in the octahedral sheets showed a decrease in crystallinity; $\mathrm{Al}$ atoms within the saponite structure were also observed to move out to non-framework positions [44].

\subsection{Thermal stability in $\mathrm{H}_{2}$}

The thermal stability of selected saponites $\left(\mathrm{Ni}^{2+}-\mathrm{CO}^{2+}\right.$, and $\mathrm{Cu}^{2+}$-containing saponites, all exchanged with $\mathrm{Al}^{3+}$ ) synthesized by Vogel et al. [44] were also studied under reducing conditions. Thermal treatment was conducted as follows. Dry samples typically weighing around $100 \mathrm{mg}$ were placed in a quartz reactor through which passed a $50 \mathrm{~mL} / \mathrm{min}$ gas flow of a $10 \% \mathrm{v} / \mathrm{v} \mathrm{H}_{2} / \mathrm{Ar}$ mixture. The temperature was then increased from 25 to $800{ }^{\circ} \mathrm{C}$ at a rate of $5{ }^{\circ} \mathrm{C} / \mathrm{min}$. $\mathrm{A} \mathrm{CO}_{2}(\mathrm{~s} / \mathrm{g})$ cold trap was used to freeze out water formed during dehydration of the sample and during reduction. The amount of $\mathrm{H}_{2}$ consumed was measured with a hot wire detector placed beyond the cold trap. The method outlined here is termed as temperature programmed reduction (TPR). 


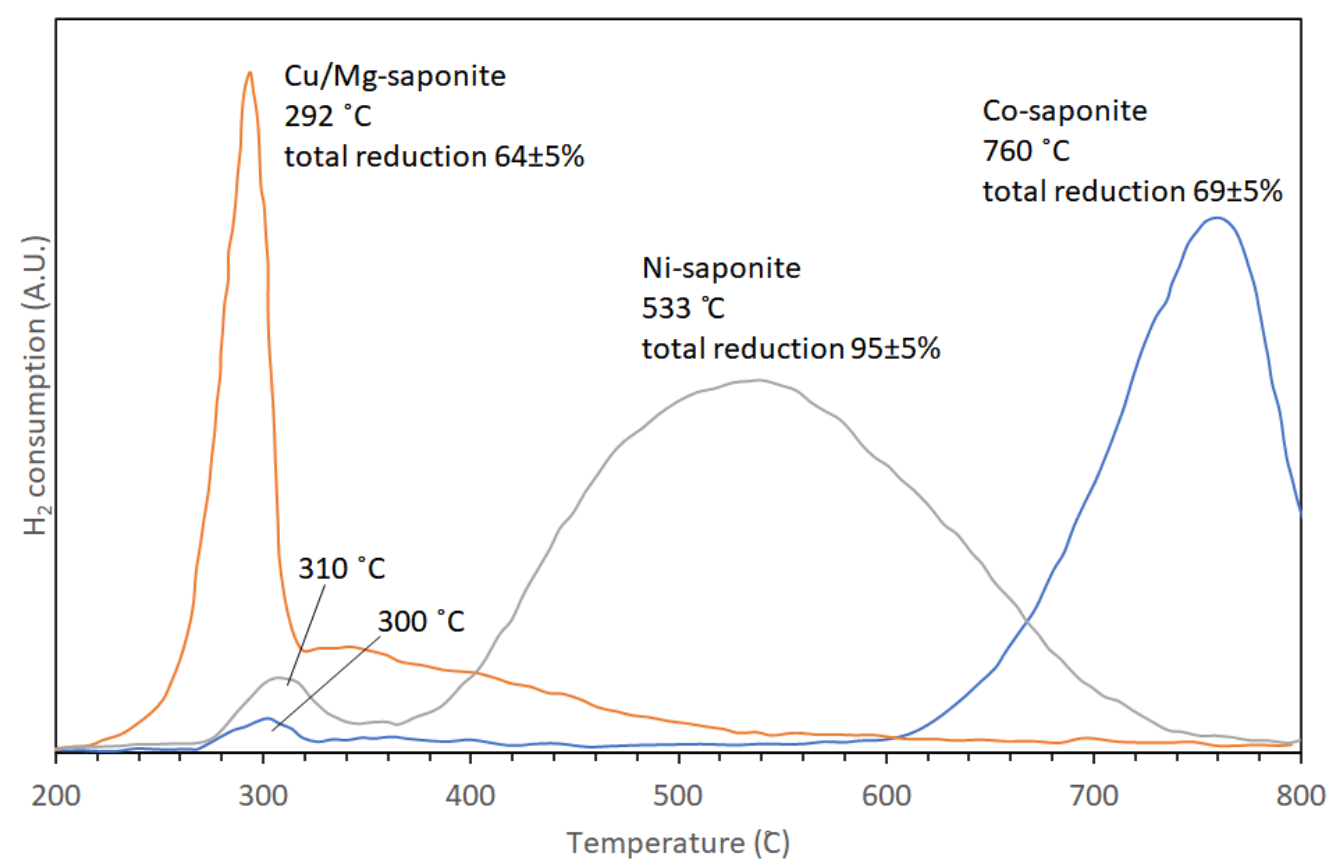

Figure 12. Temperature-programmed reduction profiles of $\mathrm{Cu}-, \mathrm{Ni}-$, and $\mathrm{Co}$-containing saponites. Modified from Figure 6 in [44].

Results of TPR experiments showed that saponites with octahedral sheets consisting of pure $\mathrm{Mg}^{2+}$ and/or $\mathrm{Zn}^{2+}$ were not reduced within the temperature range measured $\left(25-800{ }^{\circ} \mathrm{C}\right)$. $\mathrm{Cu}^{2+}$ containing saponites, however, are most easily reduced, beginning at $150^{\circ} \mathrm{C}$ with the rate of reduction increasing sharply to a peak maximum at $292{ }^{\circ} \mathrm{C}$ followed by a broad band at higher temperatures (Figure 12). The crystallinity of synthetic Cu-containing saponite as determined in [27] was poor and was suggested to be the cause of its easier reduction. Compared with the reduction temperatures observed for chrysocolla $\left[\mathrm{Cu}_{2} \mathrm{Si}_{2} \mathrm{O}_{5}(\mathrm{OH})_{2}\right][91,92]$, the reduction of the synthetic $\mathrm{Cu}^{2+}$-containing saponite proceeded at higher temperatures. This was attributed to better accessibility of the octahedral sheets of chrysocolla by hydrogen, being covered only on one side by a tetrahedral sheet. In contrast, the octahedral sheets of $\mathrm{Cu}^{2+}$-containing saponites are covered on two sides by tetrahedral sheets. $\mathrm{Ni}$ - and $\mathrm{Co}$-saponite were more resistant to reduction than $\mathrm{Cu}$-saponite. The TPR profile of Ni-saponite showed two reduction steps: a small peak centered around $310^{\circ} \mathrm{C}$ and a large broad peak (FWHM $\sim 200{ }^{\circ} \mathrm{C}$ ) centered at $533{ }^{\circ} \mathrm{C}$. Although not shown by XRD, the first TPR peak is similar to the reduction peak of $\mathrm{Ni}(\mathrm{OH})_{2}$ [93]. It was possible that some formation of $\mathrm{Ni}(\mathrm{OH})_{2}$ occurred during the authors' synthesis of $\mathrm{Ni}$-saponite. The second large reduction step was attributed to the reduction of $\mathrm{Ni}^{2+}$ present in the saponite structure as the shape was comparable albeit at lower temperatures (by 50 to $150^{\circ} \mathrm{C}$ ) to the reduction profiles obtained with nickel hydrosilicates as reported by Brahma in 1990 and Van de Loosdrecht in 1995 as cited by Vogels et al. [44]. This observed shift to lower temperatures was rationalized by taking Ni-talcs studied by Carriat et al. [92] as analogy. A decrease in the particle size of $\mathrm{Ni}$-talcs resulted in the shift in reduction maximum towards lower temperatures. This finding strongly points to a reaction rate controlled by phase boundaries. Cosaponite resisted reduction more strongly than $\mathrm{Ni}^{2+-}$ and $\mathrm{Cu}^{2+-}$ containing saponites. Similar to $\mathrm{Ni}$ saponite, the TPR profile of Co-saponite exhibited two maxima at 300 and $760{ }^{\circ} \mathrm{C}$. The small peak at $300{ }^{\circ} \mathrm{C}$ probably originated from the reduction of $\mathrm{Co}(\mathrm{OH})$. It seems plausible that the formation of some $\mathrm{Co}(\mathrm{OH})_{2}$ occurred next to Co-saponite during synthesis, similar to $\mathrm{Ni}(\mathrm{OH})_{2}$. The amount of $\mathrm{Co}(\mathrm{OH})_{2}$, measured with TPR, never exceeded $3 \%$. The main reduction step was sharper as compared to that of $\mathrm{Ni}$-saponite: reduction started at $600{ }^{\circ} \mathrm{C}$ and was not finished at the maximum measurement temperature of $800{ }^{\circ} \mathrm{C}$, resulting in a final degree of reduction of Co-saponite of only $69 \%$. It is remarkable that $\mathrm{Co}^{2+}$ in a silicate lattice is far more difficult to reduce than $\mathrm{Ni}^{2+}$, even though both (hydr)oxides exhibit similar reducibility behaviors. 


\section{Catalytic properties}

Understanding the catalytic properties of synthetic mineral surfaces in the laboratory would provide more information on how life could have emerged. Several clay minerals including saponites were studied for their potential role in catalyzing reactions in primitive Earth. For example, Ferris and co-workers demonstrated clay-catalyzed synthesis of polynucleotides. RNA oligomers containing 6-14 monomer units were synthesized from 5-phosphorimidazolide of adenine (ImpA) in the presence of montmorillonite [16]. They have also shown that longer chains ( $\sim 50$-mers) of prebiotic molecules can be obtained by incubating the activated monomers with minerals (montmorillonite for nucleotides, illite and hydroxylapatite for amino acids) [94]. Ferris and his co-workers performed studies on formation of biopolymers near the lower temperature limit. This was to address the sensitivity to hydrolysis of the oligomers and their precursors at higher temperatures. Nevertheless, several proponents support the notion that the origin of life may have started in hydrothermal vents as cited by Martin et al. in their review paper, "Hydrothermal vents and the origin of life" [12]. Williams showed that smectites (montmorillonite and saponite) may have formed a "primordial womb" where methanol enters, incubates, and synthesizes into organic molecules (to C20) under seafloor hydrothermal conditions [12]. Meñez et al. [17] proposed that Fe-rich saponite could have catalyzed the abiotic synthesis of aromatic amino acids found preserved at depths beyond the Atlantis Massif. Interestingly, the authors proposed that these syntheses may have been possible through Fe-rich saponite-catalyzed Friedel-Crafts-type reactions during the hydrothermal alteration of oceanic peridotites. Such proposal was based on the observed properties Fe-rich smectites namely pillaring effect, enhanced sorption capacity, high reducible iron content as well as on studies showing that Fe-smectites are the most efficient solid catalyst for Friedel-Crafts reactions [95]. Friedel-Craftstype reactions are the industry-preferred method for the alkylation of (hetero)arenes under the catalytic effect of Lewis or Brønsted acids. Indeed, in the works of Vogels et al. [27,44,45,50] on ureaassisted, low temperature synthesis of saponites with different octahedral $(\mathrm{Mg}, \mathrm{Zn}, \mathrm{Ni}, \mathrm{Co})$ and tetrahedral metals (Al, Ga, B), Friedel-Crafts alkylation of an arene (benzene) is one of the main reactions featured. While the saponites of Vogels et al. $[27,44,45,50]$ were not synthesized to lend credence to the clay-catalyzed synthesis of prebiotic molecules and advance understanding on the origin of life, it is important to note that their works provided information on the saponites' adsorption properties, CEC, thermal stability, effects of tetrahedral and octahedral substitution on Lewis or Brønsted acidity and on catalytic performance. This information will be important for researchers who would want to use the methods of Vogels et al. in preparing saponites that can be used for probing their potential role in catalyzing prebiotic reactions.

Most of the catalytic reactions studied using the saponites of Vogels et al. were done at harsher temperatures than normally employed in prebiotic synthesis studies. Nevertheless, discussing the reactions in this review might provide insights on the inter-relationships between structure/properties of saponites and their catalytic performance whether in industrially important reactions or in prebiotic reactions.

\subsection{Cracking of n-dodecane}

In the catalytic cracking of n-dodecane, measurements were performed in a fixed-bed nanoflow pulse system at reaction conditions of $450{ }^{\circ} \mathrm{C}$ and 4 bar total pressure. The details are described as follows. The catalyst bed was filled with $20 \mathrm{wt} \%$ synthetic saponite and $80 \mathrm{wt} \%$ silica, both of which were between 0.212 and $0.300 \mathrm{~mm}$ in size. The gas flow composing helium, $n$-dodecane, and nitrogen at concentrations of 19.5, 12.5, and $67.9 \mathrm{~mol} \%$, respectively, were pulsed at a weight hourly space velocity (WHSV) of $\sim 66 \mathrm{~h}^{-1}$ during the pulses. The $\mathrm{n}$-dodecane/catalyst ratio was set at $0.18 \mathrm{~g} / \mathrm{g}$. Gas chromatography was used to analyze the products in which the He tracer gas and $\mathrm{H}_{2}$ were detected with a thermal conductivity detector (TCD) followed by the analysis of the hydrocarbons $\mathrm{C}_{1}$ up to and including $\mathrm{C}_{5}$. A backflush was performed, and the peak was used to determine the amount of longer hydrocarbons $\left(\mathrm{C}_{6}-\mathrm{C}_{12}\right)$. The catalyst activity was assumed to follow the first reaction order reported by Corma, Miguel and Orchillés [96] on zeolite-catalyzed n-alkanes cracking and the rate 
constant expressed as $\mathrm{k}: \mathrm{k}=\left[-\ln \left(1-0.01\left(\mathrm{C}_{5}-\mathrm{yield}\right)\right)\right] /[\mathrm{ct} * \mathrm{cf}]$, where $\mathrm{C}_{5}$-yield, $\mathrm{ct}$, and cf are the total amount of $\mathrm{C}_{1}$ to $\mathrm{C}_{5}$, the contact time, and the catalyst fraction, respectively. [50]

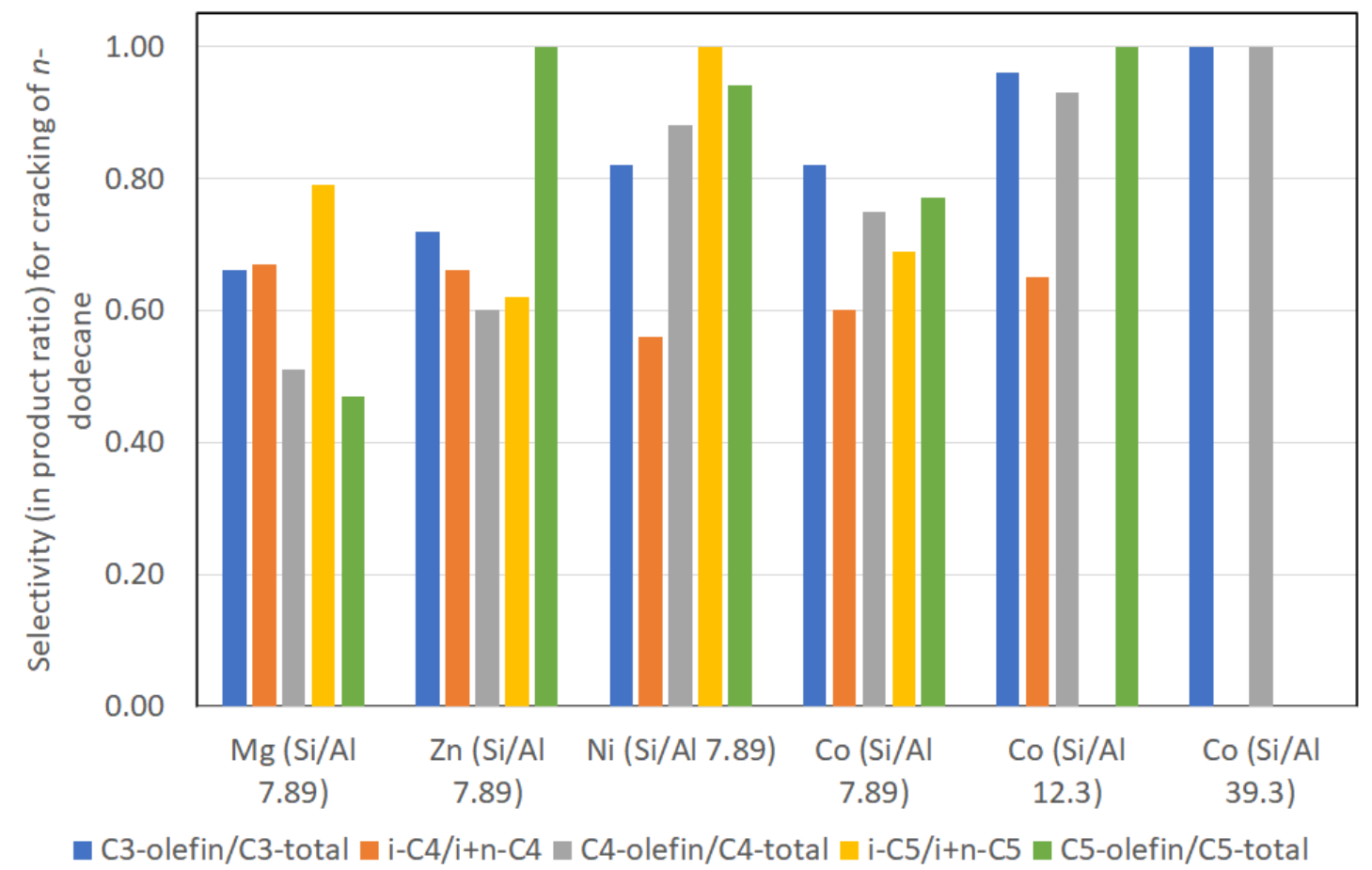

Figure 13. Selectivity expressed in product ratios for the cracking of $n$-dodecane. $C=$ paraffin, $i=$ iso, $\mathrm{n}=$ normal, total = total amount of olefins and paraffins. This figure is based on Table 2 of Vogels et al. [50].

The observed initial first-order rate constant $(\mathrm{k})$ was highest for Mg-saponite followed by $\mathrm{Co}, \mathrm{Ni}$, and $\mathrm{Zn}$. These results were explained based on the combined effects of surface area, acid strengths and ease of reduction of the metal cations in the octahedral sheets. The specific surface area of the saponites were reported as follows: 600- 750, 500-600, 400- 500, and 100- $300 \mathrm{~m}^{2} / \mathrm{g}$ for Mg-, Ni-, Co-, and $\mathrm{Zn}$-saponites, respectively. In terms of ease of reduction by hydrogen, neither $\mathrm{Mg}^{2+}$ or $\mathrm{Zn}^{2+}$ in the octahedral sheets can be easily reduced even when temperatures were raised to $800{ }^{\circ} \mathrm{C}$. Thus, the catalytic cracking behavior of $\mathrm{Mg}$ - and $\mathrm{Zn}$-saponites is due mainly to Lewis acid centers. However, carbonaceous deposits on the stronger (Lewis) acid sites resulted in substantial deactivation of Mgsaponite. $\mathrm{Ni}^{2+}$ and $\mathrm{Co}^{2+}$ ions were more susceptible to reduction by hydrogen and this resulted in saponite structure collapse. This in turn led to a loss or reduction of acid properties and subsequent lower catalytic activity. Nevertheless, the presence of $\mathrm{Co}$ and Ni metallic particles in the interlayers of the saponites afforded catalytic bifunctionality (both the metal particles and the acid sites were catalytic) for the $\mathrm{Ni}$ - and $\mathrm{Co}$-saponites. The selectivity for $\mathrm{C}_{1}-\mathrm{C}_{5}$ products was remarkable for $\mathrm{Ni}$ - and Co-saponites as shown in Figure 13. During the catalytic cracking experiments, carbon deposition occurred on metallic particles (especially on nickel where larger metallic particles were formed) and subsequently reacted with hydrogen to form methane. (Reduced) Co-saponites exhibited a high selectivity for $\mathrm{C}_{3-}, \mathrm{C}_{4-}$, and $\mathrm{C}_{5}$-olefins. This can be attributed to the smaller Co particles formed where coke build up cannot proceed rapidly, thus affecting the rate of methane formation as well. As a result, dehydrogenation prevailed in saponites containing Co particles, hence, the high selectivity for $\mathrm{C}_{3}$ - to $\mathrm{C}_{5}$ - olefins. The effect of variation in $\mathrm{Si} / \mathrm{Al}$ ratio on $\mathrm{C}_{1}-\mathrm{C}_{5}$ selectivity was detected only for $\mathrm{Co}^{-}$ saponites. [50]

\subsection{Hydro-isomerization of n-heptane.}

In the petroleum industry, isomerization is an important reaction as it converts n-alkanes into their isoparaffins of higher octane number. This paragraph discusses the isomerization reactions of 
n-heptane performed by Vogels et al. [50] in a catalytic test unit with a fixed bed reactor at a total pressure of 30 bar. Temperatures were decreased and increased between 160 and $400{ }^{\circ} \mathrm{C}$ at a rate of $0.22{ }^{\circ} \mathrm{C} / \mathrm{min}$ during reactions. The feed composition was $1: 4 \mathrm{~mol} / \mathrm{mol}$ ratio of $n$-heptane and hydrogen with the gas hourly space velocity (GHSV) of $1120 \mathrm{ml}(\mathrm{stp}) /(\mathrm{g} \mathrm{h})$. The products were analyzed with a gas chromatograph. Catalytic activity was reported as the temperature at $40 \%$ conversion. All saponite samples used in catalytic studies were pretreated (see details in Vogels et al. [50]) and were $\mathrm{H}^{+}$exchanged.

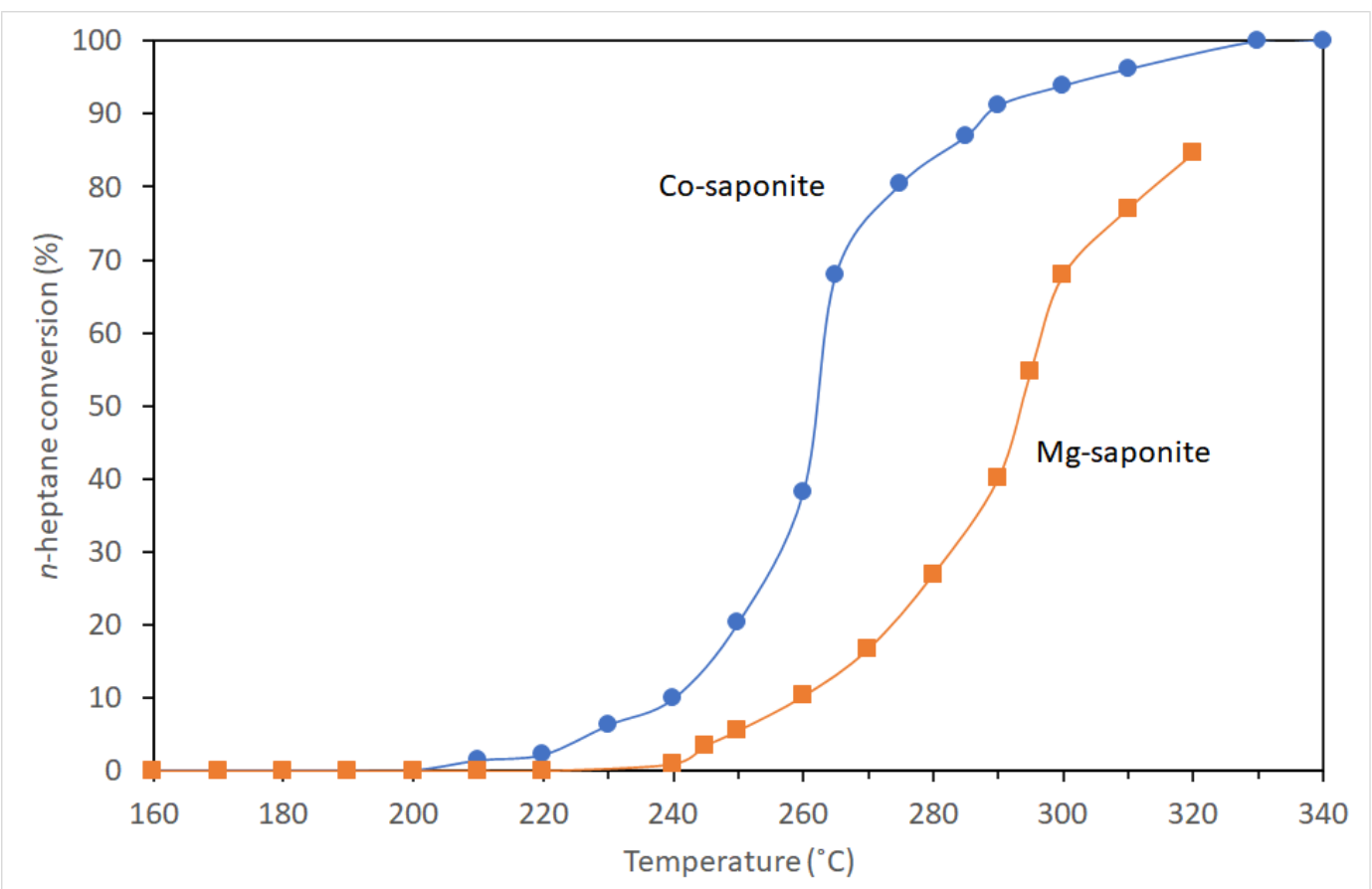

Figure 14. The conversion of $n$-heptane at rising reaction temperatures of Co-saponite ( $\mathrm{Si} / \mathrm{Al}$ ratio 7.89) and Mg-saponite (Si/Al ratio 7.89). Modified from Figure 3 in [50].

The synthetic saponite possessed almost exclusive presence of Lewis acid sites within the $\mathrm{H}^{+}$ exchanged clays. As such, it would be reasonable to relate the extent of acid-catalyzed isomerization reactions on the saponites to the Lewis acidity. Results of $n$-heptane conversion as a function of temperature for $\mathrm{Co}$ - and $\mathrm{Mg}$-saponite (Figure 14) show significantly higher conversion measured for the Co-saponite than that measured for $\mathrm{Mg}$-saponite with the same $\mathrm{Si} / \mathrm{Al}$ ratio. The difference in temperature at $40 \%$ conversion was $36{ }^{\circ} \mathrm{C}$. Notwithstanding the high activity of Co-saponite, the selectivity for $i$-heptane was low at approximately $15 \% i$ - $C_{7}$ yield between 40 and $65 \%$ conversion. In contrast, the $i-\mathrm{C}_{7}$ selectivity of Mg-saponite was $85-90 \%$. The high selectivity was retained up to $80 \%$ conversion. These differences were attributed to possible reduction of cobalt in the saponite crystal structure thereby leading to cracking instead of isomerization of $n$-heptane on the surface of metallic Co particles. It is interesting to note that the $\mathrm{Si} / \mathrm{Al}$ ratio of the saponites did not show a consistent effect in the catalytic performance. Mg-saponite showed a slightly higher activity with decreasing $\mathrm{Si} / \mathrm{Al}$ ratio at decreasing temperatures but opposite behavior in subsequent measurements at increasing temperatures. When $\mathrm{Ni}$ or $\mathrm{Co}$ were incorporated and the saponites have a mixed-metal octahedral sheet, the reaction profiles from 400 to $200^{\circ} \mathrm{C}$ were completely different from the profiles measured with the saponites containing exclusively $\mathrm{Ni}$ or $\mathrm{Co}$. The measured activities were considerably lower but the $i-C_{7}$ selectivities increased significantly. This was attributed to the accumulation of carbon on the metallic particles rendering $\mathrm{Ni}$ or Co particles in the saponites less effective in $n$-heptane cracking and the remaining (Lewis) acid sites more active in catalyzing the isomerization reaction.

The efficiency of the synthetic saponite in paraffin isomerization reactions is higher compared with an amorphous silica alumina (ASA) catalyst but lower than a commercial HZSM-5 $\left(\mathrm{H}^{+}\right.$ exchanged Zeolite Socony Mobil-5) catalyst. Nevertheless, it is clear that Lewis acid sites of the 
synthetic saponites are active towards paraffin isomerization reactions. Saponites with high Lewis acid sites may be significant in modelling polymerization and isomerization reactions of early Earth. It is interesting to note that a computational study by Rimola, Ugliengo and Sodupe [97] on formation versus hydrolysis of the peptide bond on mineral surfaces points to a combined influence of Lewis and Brønsted sites in the minerals and the London forces acting between the biomolecules and the inorganic surface on: i) condensation of glycine to yield oligopeptides as reaction products; ii) inhibition of the hydrolysis of the resulting oligopeptides. While completely different and more complex, isomerization processes (preferably one that preserves homochirality) of prebiotic molecules can possibly occur in hydrothermal compartments where simple molecules can concentrate on mineral surfaces and polymerize $[98,99]$.

\subsection{Friedel-Crafts alkylation of benzene with propylene to Cumene}

As discussed, Meñez et al. [17] proposed that Fe-rich saponite could have catalyzed the FriedelCrafts-type abiotic synthesis of aromatic amino acids in hydrothermal environments. The catalyzed Friedel-Crafts reaction performed by Vogels et al. [50] discussed in this paragraph was for industrial applications but the narrative here may be useful in understanding the catalytic activity of synthetic saponites in such reactions. The Friedel-Crafts reaction studied was the alkylation of benzene with propylene to cumene (isopropylbenzene) and was carried out in the research laboratory of Engelhard in De Meern, The Netherlands. The synthetic saponites were sieved and fractions between 0.1 and $0.4 \mathrm{~mm}$ and in concentrations of 0.2 or $1.5 \mathrm{wt} \%$ were used. These were then calcined under a nitrogen flow for $3 \mathrm{~h}$ at the desired temperature. Calcination was performed to remove water but a noncalcined and a wet saponite were also used as control samples to still determine whether water affects the catalytic performance. After the calcination, the saponites were dispersed in dry benzene and transferred to a stainless-steel autoclave. Propylene was continuously mixed into the autoclave containing an excess of benzene. The temperature was then increased to the desired level. The excess benzene (experimental benzene/propylene ratios were between 7 and 8) was necessary to avoid multiple alkylation. Details of the benzene/propylene molar ratios, catalyst, reaction temperature, and reaction duration are found in [50]. The resulting products were analyzed on a gas chromatograph with a capillary Chrompack CP-Sil-CB column and the conversion and selectivity were calculated as follows:

Conversion $=\frac{\text { mole cumene }+2(\text { mole DIPB })+3(\text { mole } T I P B \text { formed })}{\text { mole propylene in starting mixture }} \times 100 \%$,

Selectivity $=\frac{\text { mole cumene formed }}{\text { mole cumene }+2(\text { mole DIPB })+3(\text { mole } T I P B \text { formed })} \times 100 \%$.

(2)

where DIPB and TIPB stands for diisopropylbenzene and triisopropylbenzene, respectively. Products formed with negligible concentration such as n-propylbenzene and of oligomers of propylene were not included in the calculations. 


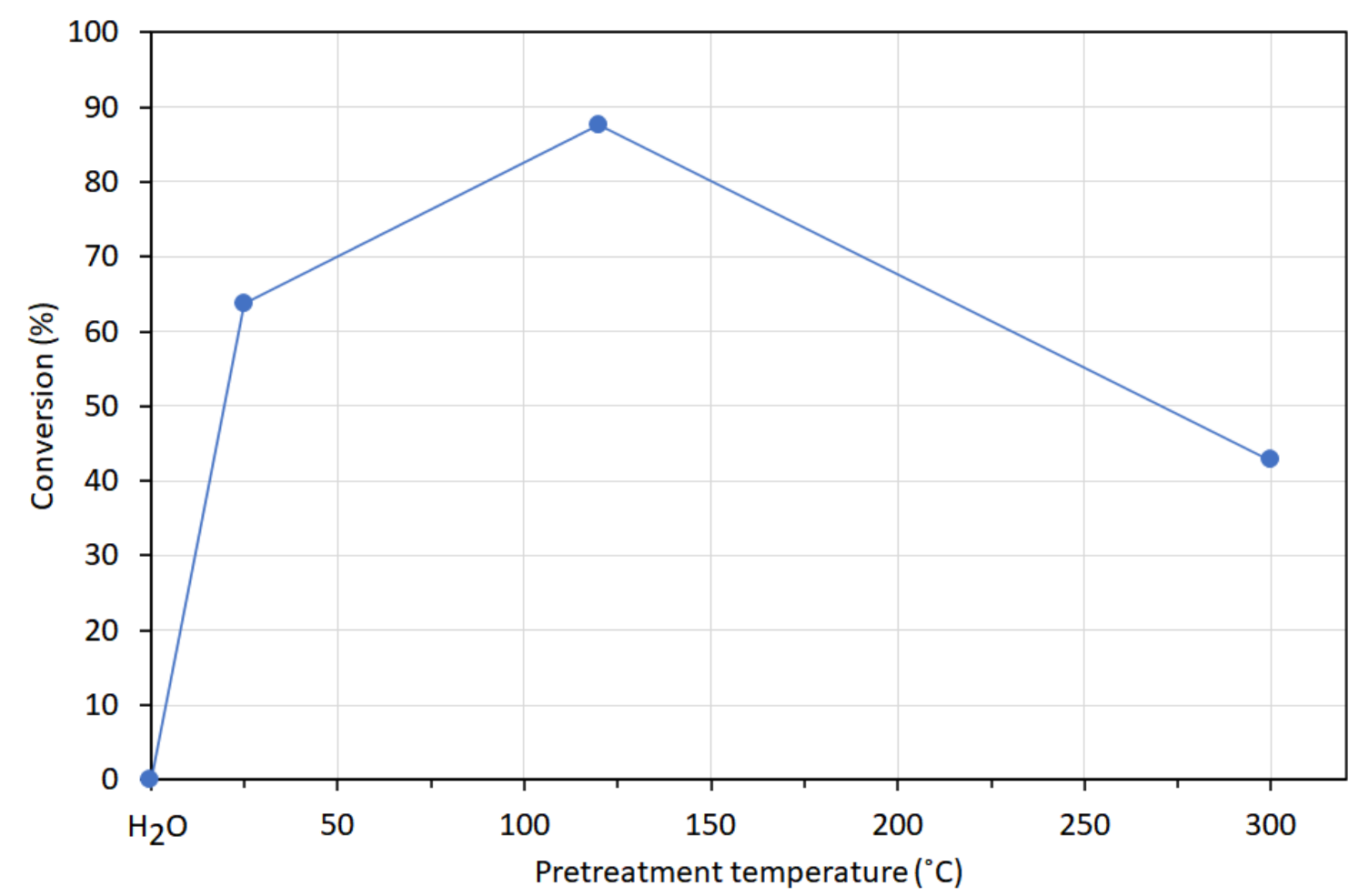

Figure 15. The influence of the hydration state of $0.2 \mathrm{wt} \% \mathrm{Zn}$-saponite (Si/Al ratio 7.89) on the catalytic activity. $\mathrm{H}_{2} \mathrm{O}$ means wet saponite sample. Reaction conditions: temperature $160{ }^{\circ} \mathrm{C}$, duration $0.25 \mathrm{~h}$, benzene/propylene molar ratio 7. Modified from Figure 5 in [50].

The conversion performance of $0.2 \mathrm{wt} \% \mathrm{Zn}$-saponite at $120{ }^{\circ} \mathrm{C}$ was $87 \%$ after $0.25 \mathrm{~h}$ (Figure 15). This amount is higher (99\%) when using $1.5 \mathrm{wt} \% \mathrm{Zn}$-saponite at $160^{\circ} \mathrm{C}$ with the selectivity not changing much between 73 and $84 \%$. The presence of water (labeled $\mathrm{H}_{2} \mathrm{O}$ in the origin of the horizontal axis) in the feed resulted in a completely deactivated $\mathrm{Zn}$-saponite. This was attributed to blocking by water of the acid sites rendering the saponites inactive towards the reactants. Increasing the pretreatment temperature to $300{ }^{\circ} \mathrm{C}$ resulted in the activity to decrease to $\sim 40 \%$. This catalytic behavior was correlated with the acid properties observed for $\mathrm{Zn}$-saponites with interlayer $\mathrm{Al}^{3+}$ where it exhibited a much higher acidity when dried at $150{ }^{\circ} \mathrm{C}$ compared when calcined at $350{ }^{\circ} \mathrm{C}$. The dissociation of water at $150^{\circ} \mathrm{C}$ within the interlayer of the exchangeable $\mathrm{Al}^{3+}$ cations may have formed Brønsted acid sites in the Zn-saponite structure. However, the nature of acid sites was not investigated. This would have been more conclusive had temperature programmed desorptionthermogravimetric (TPD-TG) analyses of n-propylamine adsorbed on saponites were performed and the results coupled with DRIFTS (diffuse reflectance infrared Fourier transform spectroscopy) runs of pyridine adsorption on the catalysts [100,101]. Adsorption of pyridine on Brønsted acid sites are typically at $1515-1565 \mathrm{~cm}^{-1}$ in the IR spectra and characteristically different from adsorption on Lewis acid sites typically at 1435-1470 $\mathrm{cm}^{-1}$ [101]. TPD-TG, on the other hand, has been used to reveal specific interactions of n-propylamine with Brønsted acid sites on the surface of acidic supports such as zeolites and silica-aluminas and was shown to quantify the amount of these acid sites better [100,102]. 


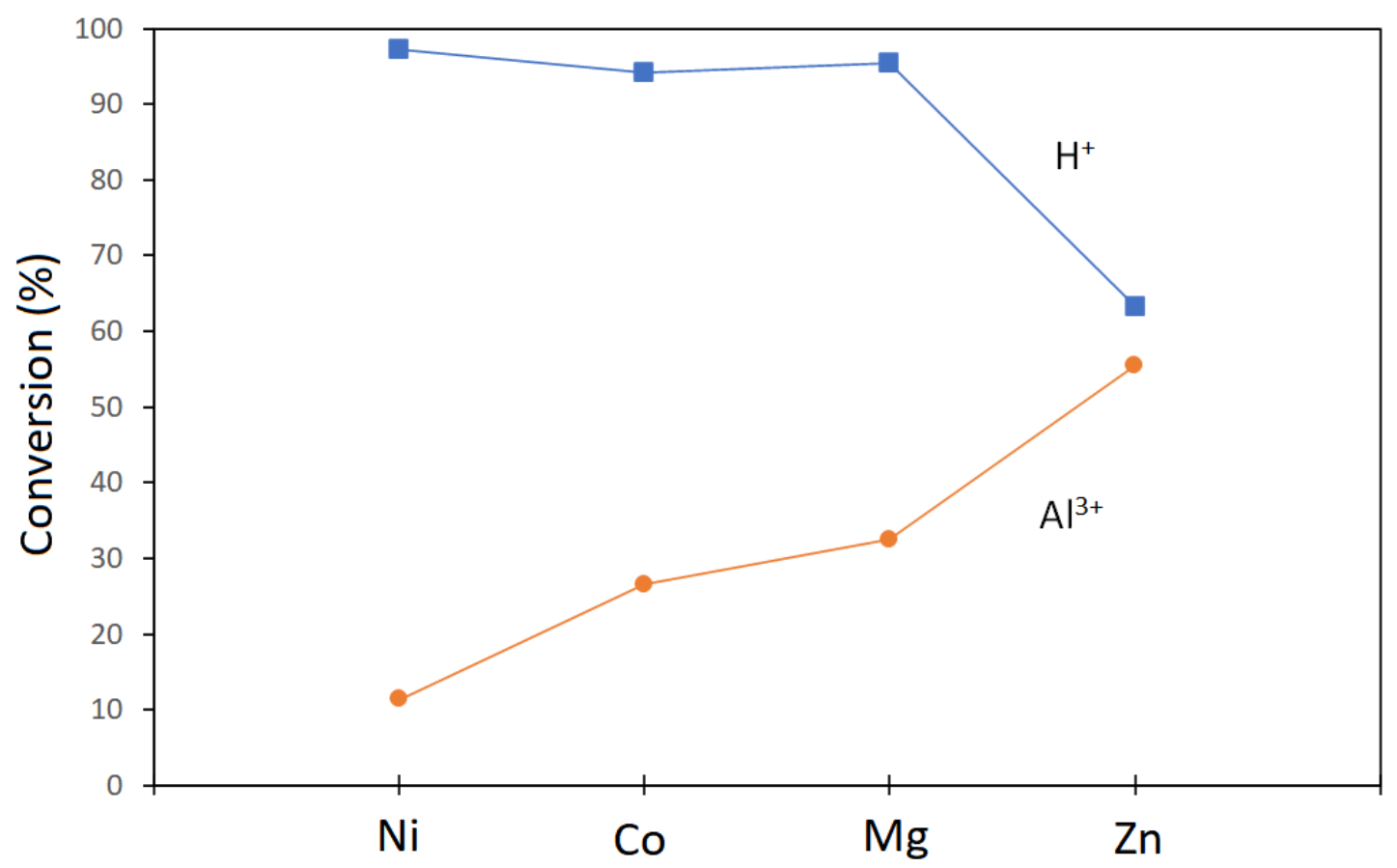

Figure 16. The influence of the composition of the octahedral sheet $\left(\mathrm{Ni}^{2+}, \mathrm{Co}^{2+}, \mathrm{Mg}^{2+}\right.$, and $\left.\mathrm{Zn}^{2+}\right)$ with (blue) $\mathrm{H}^{+}$- and (orange) $\mathrm{Al}^{3+}$-exchanged saponites (Si/Al ratio 7.89) on the catalytic performance. $\mathrm{H+-}$ saponites: $1.5 \mathrm{wt} \%$ catalyst at $190{ }^{\circ} \mathrm{C}$ and $2 \mathrm{~h}, \mathrm{Al}^{3+}$-saponites: $0.2 \mathrm{wt} \%$ catalyst at $160{ }^{\circ} \mathrm{C}$ for $0.25 \mathrm{~h}$. Modified from Figure 6 in [50].

The effect of the type of octahedral and the interlayer cation on the catalytic performance of $\mathrm{Al}^{3+}$ and $\mathrm{H}^{+}$-exchanged saponites was also investigated and the results shown in Figure 16. The $\mathrm{H}^{+}-$ exchanged $\mathrm{Ni}-, \mathrm{Mg}-$, and $\mathrm{Co}$-saponites show high catalytic activity with conversion reaching around 95\% while that of $\mathrm{Zn}$-saponite was substantially lower (63\%). Al ${ }^{3+}$-exchanged saponites, on the other hand show an opposite trend, recording low conversion for $\mathrm{Ni}$-, $\mathrm{Mg}$-, and $\mathrm{Co}$-saponites but higher conversion with $\mathrm{Zn}$-saponite. The trend in $\mathrm{H}^{+}$-exchanged saponites was rationalized based on the surface area. The interlayer space of these saponites might be too small to permit catalytic reactions. This would be more pronounced when the proton has transferred to the tetrahedral sheet cavities thereby limiting catalytic reactions to the external surface of the clay particles. The specific surface area of $\mathrm{Zn}$-saponite was significantly lower than those of the $\mathrm{Mg}-$, Ni-, and Co-saponites [27] which could have resulted in a lower catalytic activity. More isomorphous substitution of $\mathrm{Si}^{4+}$ by $\mathrm{Al}^{3+}$ increased the catalytic activity of $\mathrm{H}^{+}$-exchanged $\mathrm{Zn}$-saponite possibly due to an increase in the number of acid sites on the external surfaces. Low amount of $\mathrm{Al}^{3+}$ in the tetrahedral sheets of $\mathrm{Al}^{3+-}$ exchanged saponites resulted in a low number of acid sites, but with a relatively strong acidity. The

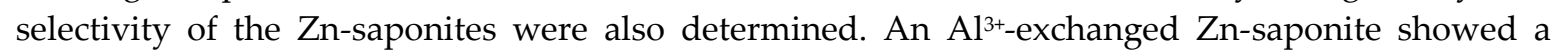
strong selectivity for $p$-DIPB. The $o$-DIPB isomer was also formed but the $m$-DIPB was present in much lower quantities even though it is the more thermodynamically favored isomer (Table 2). The authors noted that this is even more apparent at higher reaction temperatures and longer duration when $p$ - and $o$-DIPB are formed almost exclusively. Dealuminated zeolites also showed similar shape selectivity where $p$-DIPB was the preferred product $[103,104]$. Unlike in saponites, however, the ortho isomer was hardly formed in dealuminated zeolites. Shape selectivity was also reported in the pillared saponite-catalyzed alkylation of toluene by methanol to form xylene where the para isomer was formed in quantities greater than thermodynamic equilibrium calculations [105]. All of these studies attributed shape selectivity to the characteristic texture and porosity of the catalysts $[50,103,104]$. When micropores exist in these catalysts, shape-selective sorption and molecular sieving sometimes arise. These micropores can be affected by varying the size and shape of interlayer cations 
as well as by the charge and charge density of the interlayers. It would be interesting to see whether this shape selectivity of saponites apply to other reactions especially in the formation of biomolecules or their simple precursors and whether tuning the interplay of factors affecting shape selectivity can drive the exclusive formation of one isomer.

Table 2. Selectivity towards $p$-, $o$-, and $m$-diisopropylbenzene (DIPB) for $\mathrm{Al}^{3+}$-exchanged Zn-saponite $\left(\mathrm{Si} / \mathrm{Al}\right.$ ratio $=39.0$, dried at $\left.120^{\circ} \mathrm{C}\right)$

\begin{tabular}{|c|c|c|c|c|}
\hline $\begin{array}{l}\text { Conditions (catalysts } \mathrm{wt} \%, \\
\text { reaction temperature and } \\
\text { reaction time) }\end{array}$ & $\begin{array}{c}\text { Conversion } \\
(\%)\end{array}$ & $\begin{array}{c}p \text {-DIPB } \\
(\%)\end{array}$ & $\begin{array}{c}o \text {-DIPB } \\
(\%)\end{array}$ & $\begin{array}{c}m \text {-DIPB } \\
(\%)\end{array}$ \\
\hline $1.5 \mathrm{wt} \%$ catalyst, $190^{\circ} \mathrm{C}, 2 \mathrm{~h}$ & 99 & 47 & 50 & 3 \\
\hline $\begin{array}{c}1.5 \mathrm{wt} \% \text { catalyst, } 160^{\circ} \mathrm{C}, 0.25 \\
\mathrm{~h}\end{array}$ & 98 & 47 & 36 & 17 \\
\hline $\begin{array}{c}0.2 \mathrm{wt} \% \text { catalyst, } 160^{\circ} \mathrm{C}, 0.25 \\
\mathrm{~h}\end{array}$ & 87 & 49 & 35 & 16 \\
\hline
\end{tabular}

\section{Summary}

Saponite clays are easy to synthesize in large and pure form, have tunable properties and are shown to catalyze organic reactions. The method involving urea is presented as a reasonable analog of natural processes. The aluminosilicate gels in the first step of the synthesis form a 4-foldcoordinated $\mathrm{Al}^{+3}$ similar to what is found in nature such as in volcanic glass. The use of urea, a compound figuring in many prebiotic model reactions, circumvents the formation of brucite in the final saponite product by slowly releasing ammonia. This controls the hydrolysis of magnesium and enables the formation of saponite without the accompanying sudden increase in $\mathrm{pH}$ which would have precipitated brucite. The facile formation of the synthetic saponite is easily followed and verified by analytical tools such as XRD, vibrational spectroscopies, XRF, MAS-NMR, EXAFS and TEM. These tools also prove valuable in probing the integrity and the changes in the local environment of the saponites as they undergo thermal treatment whether in the presence of water or reducing environment or when they promote organic reactions on their surfaces. While the organic reactions catalyzed by saponites in this review are not the reactions that would lend credence to studies on clays and the origin of life, these studies suggest clay surfaces may have provided sites where prebiotic molecules adsorb and undergo more complex reactions.

Author Contributions: Conceptualization, CPP and JTK; validation, JTK; formal analysis, JTK; investigation, JTK; resources, JTK; data curation, JTK; writing - original draft preparation, CPP; writing - review and editing, CPP, JTK; visualization, JTK; supervision, JTK. All authors have read and agreed to the published version of the manuscript.

Funding: This research received no external funding.

Conflicts of Interest: The authors declare no conflict of interest.

\section{References}

1. Bernal, J.D. The Physical Basis of Life. Proceedings of the Physical Society. Section B 1949, 62, 597-618, doi:10.1088/0370-1301/62/10/301.

2. Cairns-Smith, A.G.; Hartman, H. Clay Minerals and the Origin of Life; Cambridge University Press: 1986.

3. Balogh, M.; Laszlo, P. Organic chemistry using clays; Springer-Verlag: 1993.

4. $\quad$ Aldersley, M.F.; Joshi, P.C.; Price, J.D.; Ferris, J.P. The role of montmorillonite in its catalysis of RNA synthesis. Applied Clay Science 2011, 54, 1-14, doi:https://doi.org/10.1016/j.clay.2011.06.011.

5. Ertem, G.; Ferris, J.P. Synthesis of RNA oligomers on heterogeneous templates. Nature 1996, 379, 238240, doi:10.1038/379238a0. 
6. Ferris, J.P.; Joshi, P.C.; Wang, K.J.; Miyakawa, S.; Huang, W. Catalysis in prebiotic chemistry: application to the synthesis of RNA oligomers. Advances in Space Research 2004, 33, 100-105, doi:https://doi.org/10.1016/j.asr.2003.02.010.

7. Joshi, P.C.; Aldersley, M.F.; Ferris, J.P. Homochiral Selectivity in RNA Synthesis: Montmorillonitecatalyzed Quaternary Reactions of D, L-Purine with D, L- Pyrimidine Nucleotides. Origins of Life and Evolution of Biospheres 2011, 41, 213-236, doi:10.1007/s11084-010-9222-1.

8. Huang, W.; Ferris, J.P. Synthesis of 35-40 mers of RNA oligomers from unblocked monomers. A simple approach to the RNA world. Chemical Communications 2003, 10.1039/B303134A, 1458-1459, doi:10.1039/B303134A.

9. Negron-Mendoza, A.; Ramos-Bernal, S.; Mosqueira, F.G. Synthesis in prebiotic clay environments induced by radiation. International Journal of Astrobiology 2004, 3, 295-300, doi:10.1017/S1473550405002193.

10. Moorbath, S. Age of the oldest rocks with biogenic components. Journal of Biological Physics 1995, 20, 8594, doi:10.1007/BF00700424.

11. Deamer, D.; Singaram, S.; Rajamani, S.; Kompanichenko, V.; Guggenheim, S. Self-assembly processes in the prebiotic environment. 2006, 361, 1809-1818, doi:doi:10.1098/rstb.2006.1905.

12. Williams, L.B.; Canfield, B.; Voglesonger, K.M.; Holloway, J.R. Organic molecules formed in a "primordial womb". Geology 2005, 33, 913-916, doi:10.1130/G21751.1 \%J Geology.

13. Aldersley, M.F.; Joshi, P.C. RNA dimer synthesis using montmorillonite as a catalyst: The role of surface layer charge. Applied Clay Science 2013, 83-84, 77-82, doi:https://doi.org/10.1016/j.clay.2013.08.009.

14. Bu, H.; Yuan, P.; Liu, H.; Liu, D.; Qin, Z.; Zhong, X.; Song, H.; Li, Y. Formation of macromolecules with peptide bonds via the thermal evolution of amino acids in the presence of montmorillonite: Insight into prebiotic geochemistry on the early Earth. Chemical Geology 2019, 510, 72-83, doi:https://doi.org/10.1016/j.chemgeo.2019.02.023.

15. Scappini, F.; Casadei, F.; Zamboni, R.; Franchi, M.; Gallori, E.; Monti, S. Protective effect of clay minerals on adsorbed nucleic acid against UV radiation: possible role in the origin of life. International Journal of Astrobiology 2004, 3, 17-19, doi:10.1017/S147355040400179X.

16. Ferris, J.P.; Ertem, G. Montmorillonite catalysis of RNA oligomer formation in aqueous solution. A model for the prebiotic formation of RNA. Journal of the American Chemical Society 1993, 115, 1227012275, doi:10.1021/ja00079a006.

17. Ménez, B.; Pisapia, C.; Andreani, M.; Jamme, F.; Vanbellingen, Q.P.; Brunelle, A.; Richard, L.; Dumas, P.; Réfrégiers, M. Abiotic synthesis of amino acids in the recesses of the oceanic lithosphere. Nature 2018, 564, 59-63, doi:10.1038/s41586-018-0684-z.

18. Bernhardt, H.S. Making Molecules with Clay: Layered Double Hydroxides, Pentopyranose Nucleic Acids and the Origin of Life. 2019, 9, 19.

19. Erastova, V.; Degiacomi, M.T.; G. Fraser, D.; Greenwell, H.C. Mineral surface chemistry control for origin of prebiotic peptides. Nature Communications 2017, 8, 2033, doi:10.1038/s41467-017-02248-y.

20. Ponnamperuma, C.; Shimoyama, A.; Friebele, E. Clay and the origin of life. Origins of life 1982, 12, 9-40, doi:10.1007/BF00926908.

21. Ferris, J.P. Mineral Catalysis and Prebiotic Synthesis: Montmorillonite-Catalyzed Formation of RNA. Elements 2005, 1, 145-149, doi:10.2113/gselements.1.3.145 \%J Elements.

22. Brack, A. Chapter 10.4 - Clay Minerals and the Origin of Life. In Developments in Clay Science, Bergaya, F., Lagaly, G., Eds. Elsevier: 2013; Vol. 5, pp. 507-521.

23. Sueoka, Y.; Yamashita, S.; Kouduka, M.; Suzuki, Y. Deep Microbial Colonization in Saponite-Bearing Fractures in Aged Basaltic Crust: Implications for Subsurface Life on Mars. Front Microbiol 2019, 10, 2793-2793, doi:10.3389/fmicb.2019.02793.

24. dos Santos, R.; Patel, M.; Cuadros, J.; Martins, Z. Influence of mineralogy on the preservation of amino acids under simulated Mars conditions. Icarus 2016, 277, 342-353, doi:https://doi.org/10.1016/j.icarus.2016.05.029.

25. Fialho, D.M.; Roche, T.P.; Hud, N.V. Prebiotic Syntheses of Noncanonical Nucleosides and Nucleotides. Chemical Reviews 2020, 120, 4806-4830, doi:10.1021/acs.chemrev.0c00069.

26. Menor-Salván, C. From the Dawn of Organic Chemistry to Astrobiology: Urea as a Foundational Component in the Origin of Nucleobases and Nucleotides. In Prebiotic Chemistry and Chemical Evolution of Nucleic Acids, Menor-Salván, C., Ed. Springer International Publishing: Cham, 2018; 10.1007/978-3319-93584-3_4pp. 85-142.

27. Vogels, R.J.M.J.; Kloprogge, J.T.; Geus, J.W. Synthesis and characterization of saponite clays. American Mineralogist 2005, 90, 931-944, doi:10.2138/am.2005.1616 \%J American Mineralogist. 
28. Kloprogge, J.T.; Breukelaar, J.; Jansen, J.B.H.; Geus, J.W. Development of Ammonium-Saponites from Gels with Variable Ammonium Concentration and Water Content at Low Temperatures. Clays and Clay Minerals 1993, 41, 103-110, doi:10.1346/CCMN.1993.0410111.

29. Kloprogge, J.T.; Breukelaar, J.; Geus, J.W.; Jansen, J.B.H. Characterization of Mg-Saponites Synthesized from Gels Containing Amounts of $\mathrm{Na}+\mathrm{K}+, \mathrm{Rb}+, \mathrm{Ca} 2+, \mathrm{Ba} 2+$, or $\mathrm{Ce} 4+$ Equivalent to The CEC of the Saponite. Clays and Clay Minerals 1994, 42, 18-22, doi:10.1346/CCMN.1994.0420103.

30. Booij, E.; Kloprogge, J.T.; Van Veen, J.A.R. Preparation, Structural Characteristics and Catalytic Properties of Large-Pore Rare Earth Element (Ce, La)/Al-Pillared Smectites. Clays and Clay Minerals 1996, 44, 774-782, doi:10.1346/CCMN.1996.0440608.

31. Vogels, R.J.M.J.; Breukelaar, J.; Kloprogge, J.T.; Jansen, J.B.H.; Geus, J.W. Hydrothermal Crystallization of Ammonium-Saponite at $200{ }^{\circ} \mathrm{C}$ and Autogenous Water Pressure. Clays and Clay Minerals 1997, 45, 17, doi:10.1346/CCMN.1997.0450101.

32. Kloprogge, J.T.; Komarneni, S.; Amonette, J.E. Synthesis of Smectite Clay Minerals: A Critical Review. Clays and Clay Minerals 1999, 47, 529-554, doi:10.1346/CCMN.1999.0470501.

33. Kawi, S.; Yao, Y.Z. Saponite catalysts with systematically varied $\mathrm{Mg} / \mathrm{Ni}$ ratio: synthesis, characterization, and catalysis. Microporous Mesoporous Mater. 1999, 33, 49-59, doi:10.1016/s13871811(99)00122-5.

34. Higashi, S.; Miki, H.; Komarneni, S. Mn-smectites: Hydrothermal synthesis and characterization. Appl. Clay Sci. 2007, 38, 104-112, doi:10.1016/j.clay.2007.01.016.

35. Carniato, F.; Bisio, C.; Gatti, G.; Roncoroni, S.; Recchia, S.; Marchese, L. On the Properties of a Novel VContaining Saponite Catalyst for Propene Oxidative Dehydrogenation. Catalysis Letters 2009, 131, 4248, doi:10.1007/s10562-009-0049-1.

36. Bisio, C.; Carniato, F.; Paul, G.; Gatti, G.; Boccaleri, E.; Marchese, L. One-Pot Synthesis and Physicochemical Properties of an Organo-Modified Saponite Clay. Langmuir 2011, 27, 7250-7257, doi:10.1021/la200892d.

37. Sychev, M.; Prihod'ko, R. Characterization and catalytic activity of non-hydrothermally synthesized saponite-like materials. Stud. Surf. Sci. Catal. 1998, 118, 967-974.

38. Xue, S.; Pinnavaia, T.J. Porous synthetic smectic clay for the reinforcement of epoxy polymers. Microporous and Mesoporous doi:https://doi.org/10.1016/j.micromeso.2007.02.042.

39. Schumann, D.; Hartman, H.; Eberl, D.D.; Sears, S.K.; Hesse, R.; Vali, H. Formation of replicating saponite from a gel in the presence of oxalate: implications for the formation of clay minerals in carbonaceous chondrites and the origin of life. Astrobiology 2012, 12, 549-561, doi:10.1089/ast.2011.0635.

40. Besselink, R.; Stawski, T.M.; Freeman, H.M.; Hövelmann, J.; Tobler, D.J.; Benning, L.G. Mechanism of Saponite Crystallization from a Rapidly Formed Amorphous Intermediate. Crystal Growth E Design 2020, 20, 3365-3373, doi:10.1021/acs.cgd.0c00151.

41. Vicente, I.; Salagre, P.; Cesteros, Y.; Medina, F.; Sueiras, J.E. Microwave-assisted synthesis of saponite. Appl. Clay Sci. 2010, 48, 26-31, doi:10.1016/j.clay.2009.11.020.

42. Trujillano, R.; Rico, E.; Vicente, M.A.; Rives, V.; Ciuffi, K.J.; Cestari, A.; Gil, A.; Korili, S.A. Rapid microwave-assisted synthesis of saponites and their use as oxidation catalysts. Appl. Clay Sci. 2011, 53, 326-330, doi:10.1016/j.clay.2010.12.005.

43. Gebretsadik, F.B.; Mance, D.; Baldus, M.; Salagre, P.; Cesteros, Y. Microwave synthesis of delaminated acid saponites using quaternary ammonium salt or polymer as template. Study of $\mathrm{pH}$ influence. Appl. Clay Sci. 2015, 114, 20-30, doi:10.1016/j.clay.2015.05.004.

44. Vogels, R.J.M.J.; Kloprogge, J.T.; Geus, J.W.; Beers, A.W.F. Synthesis and characterization of saponite clays: Part 2. Thermal stability. American Mineralogist 2005, 90, 945-953, doi:10.2138/am.2005.1617 \%J American Mineralogist.

45. Vogels, R.J.M.J.; Kloprogge, J.T.; Geus, J.W. Synthesis and characterisation of boron and gallium substituted saponite clays below $100^{\circ} \mathrm{C}$ at one atmosphere. Microporous and Mesoporous Materials 2005 , 77, 159-165, doi:https://doi.org/10.1016/j.micromeso.2004.08.027.

46. Vogels, R.J.M.J.; Kloprogge, J.T.; Geus, J.W. Homogeneous forced hydrolysis of aluminum through the thermal decomposition of urea. Journal of Colloid and Interface Science 2005, 285, 86-93, doi:https://doi.org/10.1016/j.jcis.2004.11.045.

47. Prihod'ko, R.; Sychev, M.; Hensen, E.J.M.; van Veen, J.A.R.; van Santen, R.A. Preparation, characterization and catalytic activity of non-hydrothermally synthesized saponite-like materials. Stud. Surf. Sci. Catal. 2002, 142A, 271-278.

48. Yu, B.-S.; Hung, W.-H.; Fang, J.-N.; Yu, Y.-T. Synthesis of Zn-Saponite Using a Microwave Circulating Reflux Method under Atmospheric Pressure. 2020, 10, 45. 
49. Gull, M.; Omran, A.; Feng, T.; Pasek, M.A. Silicate-, Magnesium Ion-, and Urea-Induced Prebiotic Phosphorylation of Uridine via Pyrophosphate; Revisiting the Hot Drying Water Pool Scenario. 2020, 10, 122.

50. Vogels, R.J.M.J.; Kloprogge, J.T.; Geus, J.W. Catalytic activity of synthetic saponite clays: effects of tetrahedral and octahedral composition. Journal of Catalysis 2005, 231, 443-452, doi:https://doi.org/10.1016/j.jcat.2005.02.004.

51. Kahle, M.; Kleber, M.; Jahn, R. Review of XRD-based quantitative analyses of clay minerals in soils: the suitability of mineral intensity factors. Geoderma 2002, 109, 191-205, doi:https://doi.org/10.1016/S00167061(02)00175-1.

52. Decarreau, A. Étude expérimentale de la cristallogenèse des smectites. Mesures des coefficients de partage smectite trioctahédrique -solution aqueuse pour les métaux $\mathrm{M}^{2+}$ de la première série de transition. . Sciences Geologique, Mémoire 1983 74, 1-191.

53. Infrared and Raman Spectroscopies of Clay Minerals. Gates, W.P.; Kloprogge, J.T.; Madejova, J.; Bergaya, F., Eds.; Elsevier: Amsterdam, 2017; Vol. 8, p 604.

54. Kloprogge, J.T. Application of vibrational spectroscopy in clay mineral synthesis. In Infrared and Raman Spectroscopies of Clay Minerals, Gates, W.P., Kloprogge, J.T., Madejova, J., Bergaya, F., Eds. Elsevier: Amsterdam, 2017; Vol. 8, pp. 222-287.

55. van der Marel, H.W.; Beutelspacher, H. Atlas of Infrared Spectroscopy of Clay Minerals and Their Admixtures; Elsevier: Amsterdam, 1976.

56. Kloprogge, J.T.; Frost, R.L. The effect of synthesis temperature on the FT-Raman and FT-IR spectra of saponites. Vibrational Spectroscopy 2000, 23, 119-127, doi:https://doi.org/10.1016/S0924-2031(00)00056-4.

57. Vogels, R.J.M.J.; Kerkhoffs, M.J.H.V.; Geus, J.W. Non-hydrothermal synthesis, characterization and catalytic properties of saponite clays. Stud. Surf. Sci. Catal. 1995, 91, 1153-1161.

58. Bradley, S.M.; Howe, R.F.; Kydd, R.A. Correlation between ${ }^{27} \mathrm{Al}$ and ${ }^{71} \mathrm{Ga}$ NMR chemical shifts. Magnetic Resonance in Chemistry 1993, 31, 883-886, doi:10.1002/mrc.1260311002.

59. Sanz, J.; Serratosa, J.M. Silicon-29 and aluminum-27 high-resolution MAS-NMR spectra of phyllosilicates. Journal of the American Chemical Society 1984, 106, 4790-4793, doi:10.1021/ja00329a024.

60. Turner, G.L.; Smith, K.A.; Kirkpatrick, R.J.; Oldfield, E. Boron-11 nuclear magnetic resonance spectroscopic study of borate and borosilicate minerals and a borosilicate glass. Journal of Magnetic Resonance (1969) 1986, 67, 544-550, doi:10.1016/0022-2364(86)90391-4.

61. Kim, Y.; Kirkpatrick, R.J. 11B NMR investigation of boron interaction with mineral surfaces: Results for boehmite, silica gel and illite. Geochimica et Cosmochimica Acta 2006, 70, 3231-3238, doi:https://doi.org/10.1016/j.gca.2006.04.026.

62. de Ruiter, R.; Pamin, K.; Kentgens, A.P.M.; Jansen, J.C.; van Bekkum, H. Synthesis of molecular sieve [B]-BEA and modification of the boron site Zeolites 1993, 13, 611-621.

63. Scholle, K.F.M.G.J.; Veeman, W.S. The influence of hydration on the coordination state of boron in HBoralite studied by 11B magic angle spinning n.m.r. Zeolites 1985, 5, 118-122, doi:https://doi.org/10.1016/0144-2449(85)90083-1.

64. Michot, L.J.; Villiéras, F. Chapter 2.10 - Surface Area and Porosity. In Developments in Clay Science, Bergaya, F., Lagaly, G., Eds. Elsevier: 2013; Vol. 5, pp. 319-332.

65. Matthias, T.; Katsumi, K.; Alexander, V.N.; James, P.O.; Francisco, R.-R.; Jean, R.; Kenneth, S.W.S. Physisorption of gases, with special reference to the evaluation of surface area and pore size distribution (IUPAC Technical Report). Pure and Applied Chemistry 2015, 87, 1051-1069, doi:https://doi.org/10.1515/pac-2014-1117.

66. Brunauer, S.; Emmett, P.H.; Teller, E. Adsorption of Gases in Multimolecular Layers. Journal of the American Chemical Society 1938, 60, 309-319, doi:10.1021/ja01269a023.

67. Galarneau, A.; Villemot, F.; Rodriguez, J.; Fajula, F.; Coasne, B. Validity of the t-plot Method to Assess Microporosity in Hierarchical Micro/Mesoporous Materials. Langmuir 2014, 30, 13266-13274, doi:10.1021/la5026679.

68. Morishige, K.; Tateishi, M. Accurate Relations between Pore Size and the Pressure of Capillary Condensation and the Evaporation of Nitrogen in Cylindrical Pores. Langmuir 2006, 22, 4165-4169, doi:10.1021/la053105u.

69. Sing, K.S.W. Reporting physisorption data for gas/solid systems with special reference to the determination of surface area and porosity (Recommendations 1984) \%J Pure and Applied Chemistry. 1985, 57, 603, doi:https://doi.org/10.1351/pac198557040603.

70. Cychosz, K.A.; Guillet-Nicolas, R.; García-Martínez, J.; Thommes, M. Recent advances in the textural characterization of hierarchically structured nanoporous materials. Chemical Society Reviews 2017, 46, 389-414, doi:10.1039/C6CS00391E. 
71. Zou, S.; Zhang, M.; Mo, S.; Cheng, H.; Fu, M.; Chen, P.; Chen, L.; Shi, W.; Ye, D. Catalytic Performance of Toluene Combustion over Pt Nanoparticles Supported on Pore-Modified Macro-Meso-Microporous Zeolite Foam. 2020, 10, 30.

72. Üner, O.; Bayrak, Y. The effect of carbonization temperature, carbonization time and impregnation ratio on the properties of activated carbon produced from Arundo donax. Microporous and Mesoporous Materials 2018, 268, 225-234, doi:https://doi.org/10.1016/j.micromeso.2018.04.037.

73. Pedreira-Segade, U.; Hao, J.; Razafitianamaharavo, A.; Pelletier, M.; Marry, V.; Le Crom, S.; Michot, L.J.; Daniel, I. How do Nucleotides Adsorb Onto Clays? 2018, 8, 59.

74. West, M.; Ellis, A.T.; Potts, P.J.; Streli, C.; Vanhoof, C.; Wegrzynek, D.; Wobrauschek, P. Atomic spectrometry update-X-ray fluorescence spectrometry. Journal of Analytical Atomic Spectrometry 2011, 26, 1919-1963, doi:10.1039/C1JA90038B.

75. Nicholls, D. Cobalt. In Complexes and First-Row Transition Elements, Macmillan Education UK: London, 1974; 10.1007/978-1-349-02335-6_16pp. 185-193.

76. He, H.; Li, T.; Tao, Q.; Chen, T.; Zhang, D.; Zhu, J.; Yuan1, P.; Zhu, R. Aluminum ion occupancy in the structure of synthetic saponites: Effect on crystallinity \%J American Mineralogist. 2014, 99, 109, doi:https://doi.org/10.2138/am.2014.4543.

77. Koningsberger, D.C.; Mojet, B.L.; van Dorssen, G.E.; Ramaker, D.E. XAFS spectroscopy; fundamental principles and data analysis. Topics in Catalysis 2000, 10, 143-155, doi:10.1023/A:1019105310221.

78. Koningsberger, D.C.; Miller, J.T. Local structure determination of aluminum in Y zeolite: application of low energy X-ray absorption fine structure spectroscopy. Catalysis Letters 1994, 29, 77-90, doi:10.1007/BF00814254.

79. Koningsberger, D.C.; Miller, J.T. Withdrawal of electron density by cations from framework aluminium in Y zeolite determined by Al XAFS spectroscopy. . Studies in Surface Science and Catalysis 1995, 97, 125131.

80. Koningsberger, D.C.; Miller, J.T. The development of strong acidity by non-framework aluminium in H-USY determined by Al EXAFS. In Proceedings of Proceedings of the 11th International Conference on Catalysis - 40th Anniversary, Part B, Baltimore, MD, USA; pp. 841-850.

81. Nemecz, E. Clay minerals (English translation); Akadémiai Hiadó: Budapest, 1981; pp. 547.

82. Reinholdt, M.; Miehé-Brendlé, J.; Delmotte, L.; Tuilier, M.-H.; le Dred, R.; Cortès, R.; Flank, A.-M. Fluorine Route Synthesis of Montmorillonites Containing $\mathrm{Mg}$ or $\mathrm{Zn}$ and Characterization by XRD, Thermal Analysis, MAS NMR, and EXAFS Spectroscopy. 2001, 2001, 2831-2841, doi:10.1002/10990682(200111)2001:11<2831::Aid-ejic2831>3.0.Co;2-6.

83. Bisio, C.; Gatti, G.; Boccaleri, E.; Marchese, L.; Superti, G.B.; Pastore, H.O.; Thommes, M. Understanding physico-chemical properties of saponite synthetic clays. Microporous and Mesoporous Materials 2008, 107, 90-101, doi:https://doi.org/10.1016/j.micromeso.2007.05.038.

84. Baldermann, A.; Dohrmann, R.; Kaufhold, S.; Nickel, C.; Letofsky-Papst, I.; Dietzel, M. The Fe-Mgsaponite solid solution series - a hydrothermal synthesis study. Clay Minerals 2014, 49, 391-415, doi:10.1180/claymin.2014.049.3.04 \%J Clay Minerals.

85. Marshall, W.L. Hydrothermal synthesis of amino acids. Geochimica et Cosmochimica Acta 1994, 58, 20992106, doi:https://doi.org/10.1016/0016-7037(94)90288-7.

86. Ohara, S.; Kakegawa, T.; Nakazawa, H. Pressure Effects on the Abiotic Polymerization of Glycine. Origins of Life and Evolution of Biospheres 2007, 37, 215-223, doi:10.1007/s11084-007-9067-4.

87. Woessner, D.E. Characterization of Clay Minerals by ${ }^{27} \mathrm{Al}$ Nuclear Magnetic Resonance Spectroscopy. American Mineralogist 1989, 74, 203-215.

88. Engelhardt, G.; Michel, D. High resolution solid state NMR of silicates and zeolites; Wiley: New York, 1987) pp. 300.

89. Hazen, R.M.; Wones, D.R. The effect of cation substitutions on the physical properties of trioctahedral micas. American Mineralogist 1972, 57, 103-129.

90. Gillams, R.J.; Jia, T.Z. Mineral Surface-Templated Self-Assembling Systems: Case Studies from Nanoscience and Surface Science towards Origins of Life Research. 2018, 8, 10.

91. Van der Grift, C.J.G.; Mulder, A.; Geus, J.W. Characterization of silica supported copper catalysts by means of temperature-programmed reduction. Applied Catalysis 1990, 60, 181-192.

92. Carriat, J.Y.; Che, M.; Kermarec, M.; Decarreau, A. Influence of orderdisorder parameters on the reducibility of $\mathrm{Ni}$ - and $\mathrm{Cu}$-containing silicates: application to talc and chrysocolla. Catalysis Letters 1994, 25, 127-140.

93. Gérard, P.; Lemaitre, J. Characterization of hydrous nickel containing silicates by temperature programmed reduction. Bulletin de Minéralogie 1981, 655-660.

94. Ferris, J.P.; Hill, A.R.; Liu, R.; Orgel, L.E. Synthesis of long prebiotic oligomers on mineral surfaces. Nature 1996, 381, 59-61, doi:10.1038/381059a0. 
95. Choudary, B.M.; Kantam, M.L.; Sateesh, M.; Rao, K.K.; Santhi, P.L. Iron pillared clays - efficient catalysts for Friedel-Crafts reactions. Applied Catalysis A: General 1997, 149, 257-264, doi:https://doi.org/10.1016/S0926-860X(96)00310-9.

96. Corma, A.; Miguel, P.J.; Orchille's, A.V. Influence of hydrocarbon chain length and zeolite structure on the catalyst activity and deactivation for n-alkanes cracking. Applied Catalysis A: General 1994, 117, 2940, doi:https://doi.org/10.1016/0926-860X(94)80156-8.

97. Rimola, A.; Ugliengo, P.; Sodupe, M. Formation versus hydrolysis of the peptide bond from a quantummechanical viewpoint: The role of mineral surfaces and implications for the origin of life. Int J Mol Sci 2009, 10, 746-760, doi:10.3390/ijms10030746.

98. Martin, W.; Baross, J.; Kelley, D.; Russell, M.J. Hydrothermal vents and the origin of life. Nature Reviews Microbiology 2008, 6, 805-814, doi:10.1038/nrmicro1991.

99. Toxvaerd, S. Origin of homochirality in biosystems. Int J Mol Sci 2009, 10, 1290-1299, doi:10.3390/ijms10031290.

100. Leliveld, B.R.G.; Kerkhoffs, M.J.H.V.; Broersma, F.A.; van Dillen, J.A.J.; Geus, J.W.; Koningsberger, D.C. Acidic properties of synthetic saponites studied by pyridine IR and TPD-TG of n-propylamine. J. Chem. Soc., Faraday Trans. 1998, 94, 315-321.

101. Emeis, C.A. Determination of Integrated Molar Extinction Coefficients for Infrared Absorption Bands of Pyridine Adsorbed on Solid Acid Catalysts. Journal of Catalysis 1993, 141, 347-354, doi:https://doi.org/10.1006/jcat.1993.1145.

102. Biaglow, A.I.; Gittleman, C.; Gorte, R.J.; Madon, R.J. 2-Propanamine adsorption on a fluid catalytic cracking catalyst. Journal of Catalysis 1991, 129, 88-93, doi:https://doi.org/10.1016/0021-9517(91)90011-R.

103. Meima, G.R.; van der Aalst, M.J.M.; Samson, M.S.U.; Garces, J.M.; Lee, J.G. Cumene production based on modified mordenite catalysts. In Proceedings from the Ninth International Zeolite Conference, von Ballmoos, R., Higgins, J.B., Treacy, M.M.J., Eds. Butterworth-Heinemann: 1993; https://doi.org/10.1016/B978-1-4832-8383-8.50124-0pp. 327-334.

104. Kaeding, W.W. Shape-selective reactions with zeolite catalysts: VII. Alkylation and disproportionation of cumene to produce diisopropylbenzene. Journal of Catalysis 1989, 120, 409-412, doi:https://doi.org/10.1016/0021-9517(89)90280-7.

105. Urabe, K.; Sakurai, H.; Izumi, Y. Pillared synthetic saponite as an efficient alkylation catalyst. Journal of the Chemical Society, Chemical Communications 1986, 10.1039/C39860001074, 1074-1076, doi:10.1039/C39860001074. 